\title{
Information system on hydrological and geomorphological catastrophes in Italy (SICI): a tool for managing landslide and flood hazards
}

\author{
F. Guzzetti and G. Tonelli \\ Consiglio Nazionale delle Ricerche, Istituto di Ricerca per la Protezione Idrogeologica, via della Madonna Alta 126, 06128 \\ Perugia, Italy
}

Received: 13 October 2003 - Revised: 20 January 2004 - Accepted: 22 January 2004 - Published: 15 April 2004

Part of Special Issue "Geo-databases for Natural Hazards and Risk Assessment"

\begin{abstract}
Since 1990, we have maintained a database of historical information on landslides and floods in Italy, known as the National Research Council's AVI (Damaged Urban Areas) archive. The database was originally designed to respond to a request of the Minister of Civil Protection, and was aimed at helping the regional assessment of landslide and flood risk in Italy. The database was compiled in 19911992 to cover the period 1917 to 1990 , and then updated to cover systematically the period 1917 to 2000, and nonsystematically the periods 1900 to 1916 and 2001 to 2002 . The database currently contains information on more than 32000 landslide events occurred at more than 21000 sites, and on more than 29000 flood events occurred at more than 14000 sites. Independently from the AVI archive, we have obtained other databases containing information on damage caused by mass movements and inundations, daily discharge measurements and solid-transport measurements at selected gauging stations, bibliographical and reference information on landslides and inundations, and a catalogue of National legislation on hydrological and geological hazards and risk in Italy. The databases are part of an information system known as SICI (an Italian acronym for Sistema Informativo sulle Catastrofi Idrogeologiche, Information System on Hydrological and Geomorphological Catastrophes), which is currently the largest single repository of historical information on landslides and floods in Italy. After an outline of the history and evolution of the AVI Project archive, we present and discuss: (a) the structure of the SICI information system, including the hardware and software solutions adopted to maintain, manage, update, use and disseminate the information stored in the various databases, (b) the type and amount of information stored in each database, including an estimate of their completeness, and (c) examples of recent applications of the information system, including a web-based GIS system to
\end{abstract}

Correspondence to: F. Guzzetti

(fausto.guzzetti@irpi.cnr.it) show the location of sites historically affected by landslides and floods, and an estimate of geo-hydrological (i.e. landslide and flood) risk in Italy based on the available historical information.

\section{Introduction}

Inundations and landslides are frequent in Italy and historical information describing landslides and floods dates back to the Roman Age. The oldest known flood along the Tiber River in Rome occurred in 414 BC. Pliny the Elder reported landslides triggered by a large earthquake occurred during the Battle of Trasimeno, in the second Punic War in $264 \mathrm{BC}$. The societal and economic impact of flooding and slope failures is high in Italy. In the 20th century, a period for which the information is available, the toll amounts to: 10000 deaths, missing persons and injured people, more than 700000 homeless people, thousands of houses and bridges and hundreds of kilometres of roads and rails destroyed or damaged, and impact on the cultural heritage which is unmatched in any other country. In the last two decades of the 20th century floods, debris-flows and landslides have caused damage estimated in excess of EUR 17000, a figure that is probably underestimated (Fig. 1). In the Appendix A we briefly describe some of the most catastrophic landslide and flood events in the period from 1950 to 2000 , including the type and extent of damage.

For the past fourteen years we have maintained and updated a database of historical information on landslides and floods in Italy, known as the National Research Council's AVI (Damaged Urban Areas) archive (Guzzetti et al., 1994). The database originally covered the period 1917 to 1990 and was subsequently updated to cover systematically the period from 1917 to 2000, and non-systematically the periods from 1900 to 1916 and from 2001 to 2002. Starting in 1998 and 


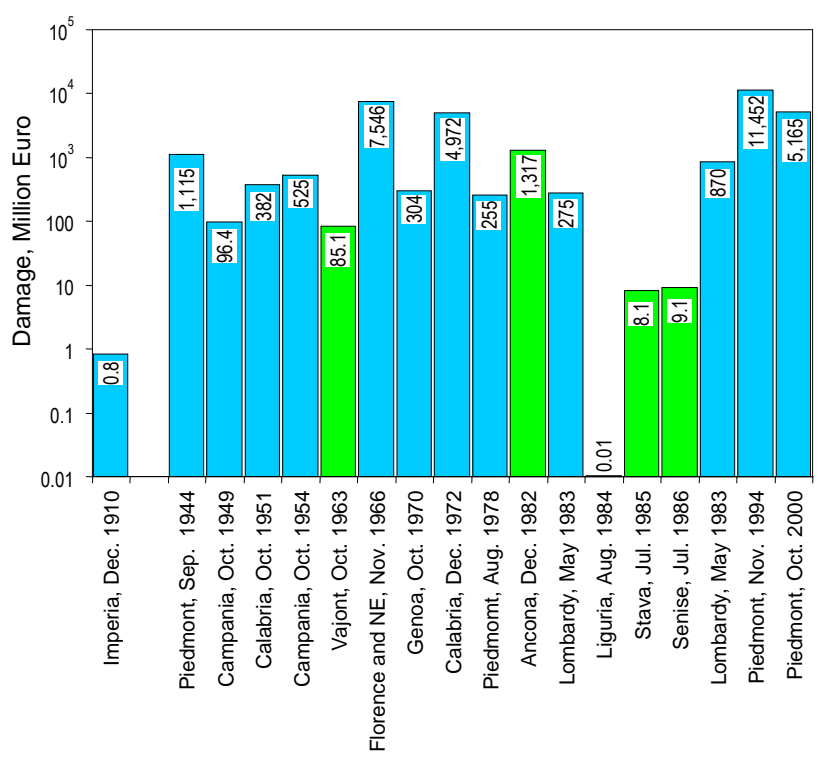

Fig. 1. Economic damage produced by individual landslides and flooding events in Italy in the period from 1910 to 2000. Green bars are single landslide events. Blue bars are multiple landslides and flooding events.

independently from the AVI archive, we have assembled a collection of databases and digital catalogues containing a variety of historical, geographical, and bibliographical information on landslides and floods in Italy. The databases contain data on damage caused by mass movements and inundations, daily discharge measurements and solid-transport measurements at selected gauging stations, bibliographical and reference information on landslides and inundations, and a catalogue of national legislation on hydrological and geological hazards and risk, which is copious in Italy.

Beginning in 1999, we have merged the AVI project database and the other digital catalogues into a single information system on hydrologic and geomorphologic hazards and risk. The information system, known as SICI (an Italian acronym for Sistema Informativo sulle Catastrofi Idrogeologiche, Information System on Hydrological and Geomorphological Catastrophes), is the largest, publicly available source of information on landslide and flood hazards and risk in Italy. In this paper, we illustrate the history and the recent evolutions of the AVI archive, including the latest products, and we introduce SICI, presenting the structure and content of the information system, and describing the adopted hardware and software solutions. We then present and discuss recent applications of the available historical information on mass movements and inundations to help ascertaining landslide and flood hazards and risk in Italy.

\section{The AVI Project archive}

On 23 June 1989, the Italian Minister of Civil Protection requested the Italian National Research Council (CNR),
Group for Hydrological and Geological Disasters Prevention (GNDCI), to compile an inventory of sites historically affected by landslides and floods in Italy, for the period 19181990 (Guzzetti et al., 1994). The idea of collecting historical information on natural catastrophes was not new in Italy. Toward the end of XIX century natural scientists collected a wealth of information on a variety of natural disasters including epidemics (Corradi in 1865-1894), earthquakes (Mercalli in 1883 and Baratta in 1901), floods (Bottoni in 1873), and landslides (Almagià in 1907-1910). More recently, large and expensive efforts have been made to collect historical information on earthquakes and their effects (Postpischl, 1985; Boschi et al., 1997).

To respond to the Minister request, CNR GNDCI in 19901992 designed and completed an inventory of historical information on landslides and floods in Italy. The project became known as the AVI project. Between 1991 and 1992 seventeen teams collected information on mass-movements and floods occurred in Italy in the 20th century. Guzzetti et al. (1994) described the original inventory, including the framework to collect, compile and summarize the information, the structure of the database used to store the data, a critical analysis of the type and amount of information collected, a description of the preliminary results obtained, and a discussion of possible applications of the historical information.

Since 1992, we have made considerable efforts to keep the database updated and to search for new data on historical landslide and flood events. The inventory was fist updated for the period 1991-1996 by searching 55 local or regional journals, for a total of more than 120000 newspaper issues screened. Updates for the period 1997-1998 and for the period 1999-2000 were completed though the systematic search of 59 local and regional newspapers, and the review of technical and events reports, and of scientific papers and books published by CNR GNDCI. Newspapers maintaining a web site were an additional source of information on recent events, and on occasion they provided detailed accounts of old events. Since 1999, we check daily the web pages of eleven regional and national newspapers searching for information on landslides and floods. An average of 700 newspaper articles is found every year, which represent about $75 \%$ of the information found through the traditional systematic screening of local and regional newspapers carried out in the newspaper libraries. The web sites of local and regional governments and of regional or national offices provided additional documents and reports on recent and historical landslide and flood events.

We also made significant efforts to check, validate, organize and disseminate the information on landslides and floods. Our activities included:

- Validation of the project database, including the correction of all typing, grammatical and language errors present in the numerous (329) database fields. We compared the information stored into the database against the original archive material compiled during 
the inventory, and we moved information written in the wrong section during the compilation of the inventory in the appropriate fields of the database.

- Storage in the database of all the "source forms" (i.e. forms used to store information on an individual event obtained from a single source of information; see Guzzetti et al., 1994) compiled during the main inventory phase in 1990-1992, and which were not originally digitized. Digitization of these forms increased the database content by about $25 \%$.

- Digitization of the original newspaper articles as Adobe Acrobat ${ }^{\circledR}$ Portable Document Format (PDF) files. Approximately 22100 newspaper articles were digitized, and scanning of the remaining articles is in progress. During the three successive updates of the inventory, new articles found in the journal libraries ("emeroteca") were scanned on site and latter transformed into PDF files. More recently, articles found in the Internet are saved directly as PDF files.

- Definition of an efficient structure for the database used to store the information on historical landslides and floods. We adjusted the relational structure of the database to accommodate new information, to respond to new research needs, and to allow for the optimal dissemination of the information through the Internet. We designed specific software to manage the information and to help collect new information.

- Definition of the geographical coordinates of the sites historically affected by landslides and floods. The geographical coordinates were obtained through a long and difficult work that involved: careful reading of the original source of information (i.e. newspaper article, technical report, scientific publication, etc.), locating the site affected by the damaging event on topographic maps or road atlases, mapping the location of the landslide or the inundated site as a point on topographic maps at 1:100000 or 1:25000 scale, and obtaining the geographical coordinate through digitization. A degree of certainty in the location was given to each site, coping with the inevitable uncertainty in the location of many sites based on their name. Sites for which the location was undetermined were mapped in the municipality chief town.

\subsection{Type and abundance of information}

The three main sources of information used to compile the inventory were newspapers, the review of the technical and scientific literature, and interviews. The various sources of information provided information of different quality and in different amounts. We estimate that about $78 \%$ of the total information currently stored in the AVI archive comes from newspapers, $20 \%$ from technical and scientific documents, and the remaining $2 \%$ from interviews. Newspapers emphasize large-magnitude events that occurred in urban areas or that caused damage to well-known or easily recognizable structures. They under-report events of low magnitude or those that do not cause extensive or well-defined damage. The bias limits the definition and the full extent of the hazard in agricultural and rural areas. Newspapers also emphasize the reactivation and repetition of mass movements and floods. The amount and reliability of information found in newspapers improved after Word War II. It increased during the 1950s when several journals introduced regional and local chronicles, and markedly increased in the 1990s when many more journals were searched. The review of newspaper articles provides quality data on the date (but rarely the time) and the general triggering mechanism (rainfall, earthquake, etc.) of occurrences. The exact location is rarely reported and only for single, large events. Commonly, large areas are described where numerous landslides or bank overflows occurred. Economic estimates of the type and extent of damage is provided in a few articles, but technical data, such as the type of movement and the kind and volume of material involved, are seldom reported. A problem with newspapers lies in the reliability and correctness of the information. Quite often, different newspapers provide conflicting information on the same event. This is often the case for the same newspaper in different articles. Following (or during) a catastrophic event, journalists rarely have the opportunity, time and resources to properly crosscheck the sources of information, although they should do it. We cope with this problem with information redundancy. For each event, we collect all the articles we can find. When more than a single information or figure is available for the same flood or landslide event, the one judged to be best documented or more reliable is chosen. Often, more than one value, or a range of values, is stored in the database, indicating uncertainty in the data.

Review of technical and scientific documents provided high-quality data for a limited number of events. These documents supply information on the geological, morphological, and geotechnical characteristics of a single mass movement, and the hydrological and meteorological characteristics of a particular flooding event. Most of them contain maps and drawings describing in detail the location and the geometrical characteristics of landslides and the extent of inundated areas. This information was particularly useful to locate precisely the mass movements and the inundated areas. Curiously, scientific papers rarely describe the types and extent of damage and the societal and economic consequences of floods and landslides. Such information is more abundant in the technical or events reports and in the rare books or monographs written on particular, highly catastrophic events. Damage estimates and the societal and economic impact of landslides and floods are also available in newspaper articles.

To update the inventory, particularly useful were reports on specific or recent flooding and landslide events (e.g., Mortara et al., 1986; Gabriele, 1997; Rosso and Serva, 1998; Tropeano et al., 1993, 1995, 1999, 2000; Tropeano and Turconi, 2000, 2002; Regione Piemonte, 1996, 1998, 2000a, 2000b; D'Andrea and Petrucci, 2003), historical catalogues 


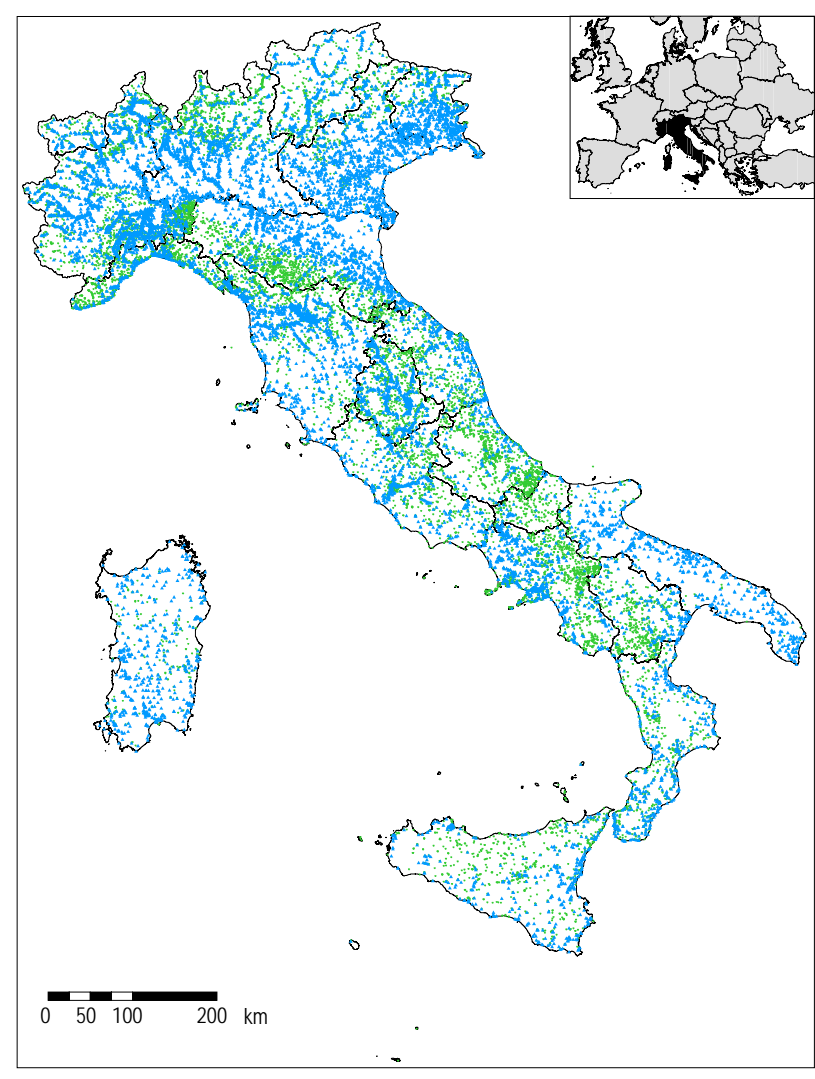

Fig. 2. AVI project archive. Geographical distribution of the sites historically affected by landslides (green dots) and inundations (blue triangles) in Italy in the period from 1900 to 2002.

of landslides and floods compiled for specific geographical areas (e.g. Natoli, 1944; Eisbacker and Clague, 1984; Tropenano, 1989; Catenacci, 1994; Felciai and Preti, 1996; Bellardone, 1996; Trioisi, 1997; Migale and Milone, 1998; Monticelli, 1998), regional flood and hydrological reports (Versace et al., 1987; Cao et al., 1991; Copertino and Fiorentino, 1994; Cannarozzo et al., 1993; Rossi and Villani, 1995; Villi and Bacchi, 2001), and regional atlases of landslides in urban areas (Bozzo et al., 1988; Annovi and Simoni, 1993; Luino et al., 1993; Felicioni et al., 1995; Agostoni et al., 1997a, 1997b, 2000; Canuti et al., 2000; Federici et al., 2001; Collalti et al., 2002).

Interview with experts in the fields of mass movements and floods provided general information on a limited number of hydrological events. The interviews were conducted only in 1990-1992 and were useful in giving a comprehensive overview of the areas historically affected by landslides or floods and in defining the awareness of the scientific and technical communities to the problem of geo-hydrological hazards in each region.

\subsection{Available products}

In spite of the limitations due to the complexity of the Italian landscape, the different awareness of the impact of land-
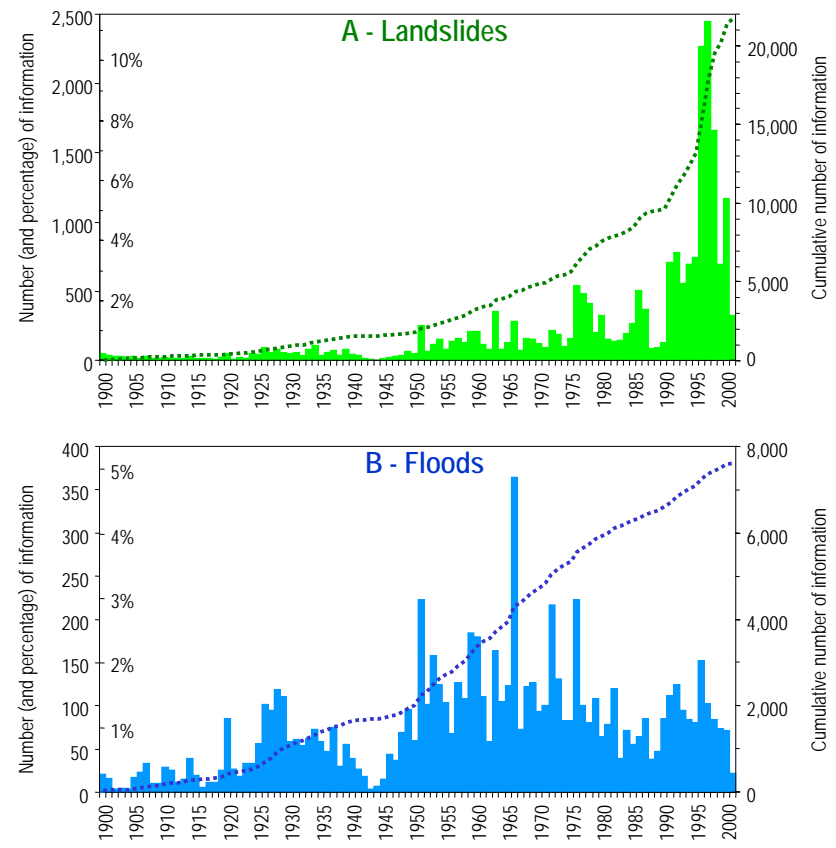

Fig. 3. AVI project archive. Temporal distribution of historical information on landslides (A) and floods (B) in the period form 1900 to 2002 . Histograms show the number and percentage of information. Dashed lines show the cumulative number of information.

slides and floods, and the limited resources available for the inventory and its maintenance and upgrade, the result of the AVI inventory represents the most comprehensive source of information on mass-movements and floods ever prepared for Italy. The database currently contains 31182 entries on 32162 landslide events that occurred at 21159 sites (equivalent to a density of about 1 landslide site per $14 \mathrm{~km}^{2}$ ) and 8518 entries on 29233 inundation events at 15904 sites (equivalent to a density of about 1 inundated site per $19 \mathrm{~km}^{2}$ ). In the database, information on landslides most commonly refers to individual slope failures, whereas information on floods generally lists several sites that were inundated during the same flooding events. This explains the comparably smaller number of entries on floods. Figure 2 shows the geographical distribution of the sites historically affected by landslides and floods, and Fig. 3 shows the temporal distribution of the historical information on slope failures and inundations in Italy, from 1900 to 2002. Stored in the database are about 90000 newspapers articles with information on hydrological or geological catastrophes; $24 \%$ of them are available as PDF files.

To disseminate the wealth of information stored in the AVI archive we prepared various products, including maps, catalogues, databases and web sites. Guzzetti et al. (1996) published the first synoptic map of the sites historically affected by landslides and floods in Italy. The map was published at 1:1200000 scale and showed the approximate location of 11455 landslide events and 5385 flood events. The map exhibited a distinct lack of homogeneity in the 
geographical distribution of sites affected by landslides or floods, indicating the need for a more precise location of the affected sites. This was accomplished in 1997 using medium- and large-sale topographical maps. In Reichenbach et al. (1998b)published a second edition of the map, which portrayed the location of more than 15000 sites (9086 landslides and 6456 floods) affected by catastrophic events for the period 1918-1994. The new map showed the location of 2608 landslide sites and 2317 inundation sites which were affected recursively, i.e. more than once during the 77-year investigated period. In a separate box of the map, histograms showed for each of the twenty Italian regions, the number of inundated sites against the number of times each site was inundated. The graphs revealed that for most of the regions the number of inundated sites was large, confirming that flooding is widespread in Italy, but also that sites more frequently inundated are relatively few, indicating that the number of sites at "high risk" is limited. CNR GNDCI distributed the synoptic maps of Guzzetti et al. (1996) and of Reichenbach et al. (1998b) to all the Italian Senators and Chamber Representatives.

The exact or the approximate date of occurrence is known for many slope movements and inundations. Combined with the information on the location of the events, the date allowed us to prepare the first national catalogue of sites historically affected by landslides or floods in Italy. Cardinali et al. (1998b) collected this information in a book, in two volumes, which lists the date (day, month and year) and location (i.e. region, province and municipality) of 23606 landslide events at 15956 sites, and of 25078 flooding events at 13494 sites. For floods, the river, torrent or stream that caused the inundation is reported, where the information is available. The catalogue was also available on a CD-ROM built with GIS technology and capable of showing the distribution of damaged sites (Cardinali et al., 1998a). CNR GNDCI distributed about 2000 copies of the book and of the CD-ROM to national and local civil protection authorities, to planners and decision makers, to private consultants involved in civil defence planning, and to schools, environmental associations and concerned citizens.

In the attempt to disseminate the information collected by the AVI project, we designed a specific web site (http: //avi.gndci.cnr.it). The web site contains general information on the project and its main results, and allows access to the project reports, to scientific papers and technical documents, to statistics summarizing the number of information collected in the 20 regions, the 103 provinces and the 8103 municipalities in Italy. From the web site, one can download databases (in Microsoft Access ${ }^{\circledR}$ format) containing part of the information stored in the main project archive. This feature is not available for the most recent releases of the archive, which are available on line from SICI, the information system on historical landslides and floods in Italy. A second web site (http://sicimaps.irpi.cnr.it) exploits GISbased web technology to display maps of the distribution of sites affected by the historical landslides and floods in Italy.

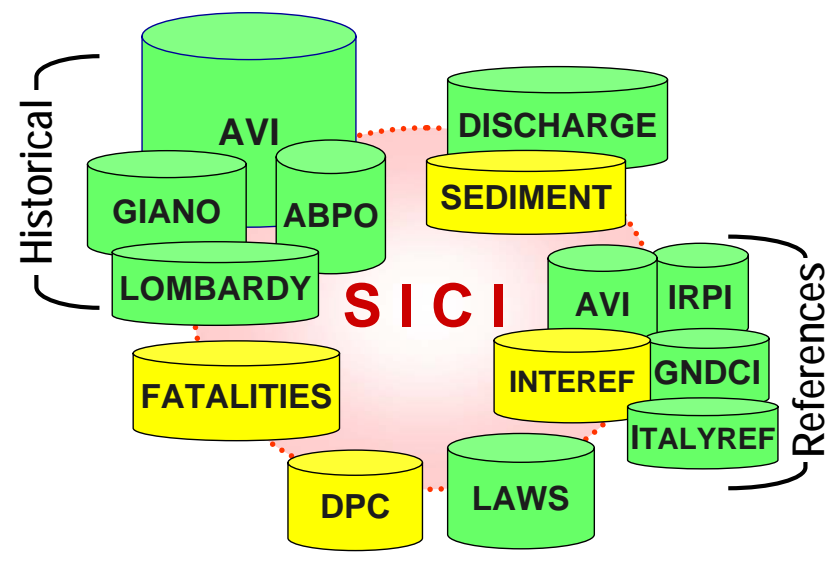

Fig. 4. SICI, the information system on historical landslides and floods in Italy. Modules available in the database. Legend: green cylinders, modules publicly available trough the SICI home page (http://sici.irpi.cnr.it); yellow cylinders, modules with restricted access.

\section{SICI, an information system on historical landslides and floods}

The large amount of available historical data, the complexity of the AVI database, and increasing requests from the national, regional and local governments, from scientists, geologists, engineers and planners, from civil protection personnel and concerned citizens, has guided the transition of the AVI database from a simple storage of historical data into an information system on landslide and flood events capable of responding to the requests of different users. SICI is a collection of databases containing historical, geographical, damage, hydrological, and bibliographical information on landslides and floods in Italy. SICI is accessible trough the internet at the Universal Resource Location (URL) address http://sici.irpi.cnr.it.

Instead of embarking into a troublesome and error prone effort to merge the various databases into a single archive, we decided to keep all the databases separate, and to treat them as different sources of information within a single information system. SICI currently contains ten modules, seven of which are completely or partially available to the public (Fig. 4). The modules are:
a) AVI
b) GIANO
c) FATALITIES
d) $\mathrm{ABPO}$
e) LOMBARDY
f) DPC
g) LAWS
h) REFERENCES
i) DISCHARGE
j) SEDIMENT

The AVI module contains the database of the AVI project described before. It represents the largest and most important module of SICI, at least for the 20th century. The latest 


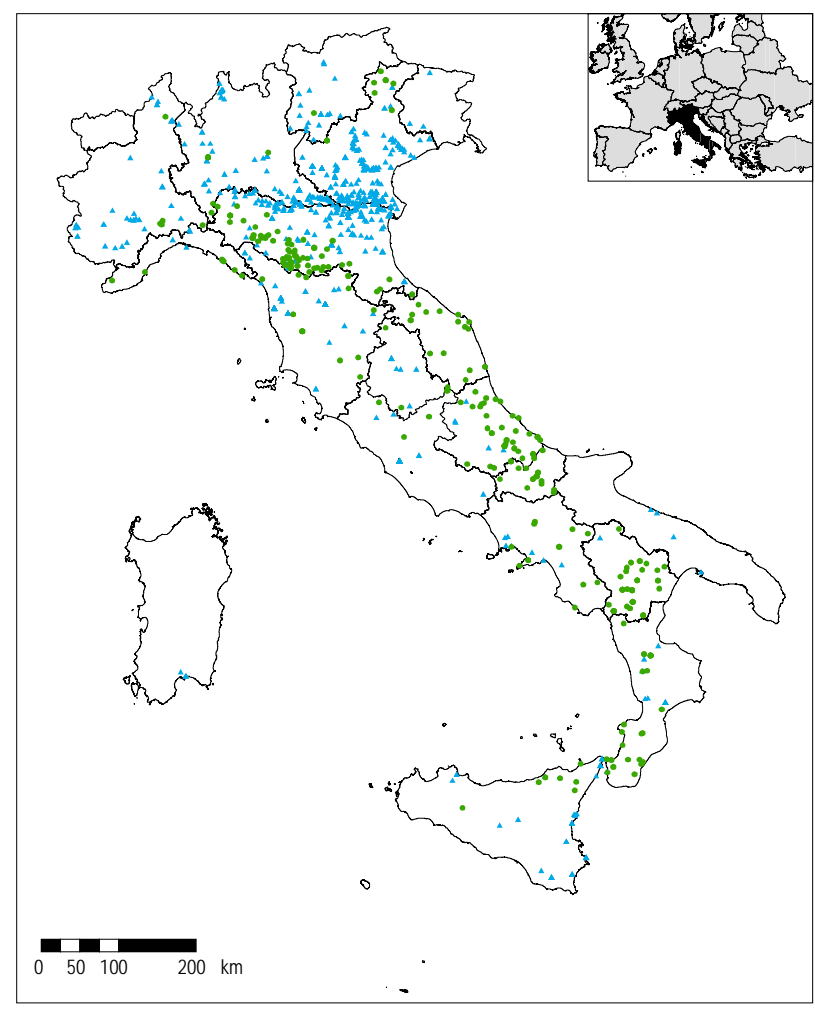

Fig. 5. GIANO module. Geographical distribution of 356 landslides (green dots) and 793 inundations (blue triangles) inventoried in the GIANO database in the period from 1700 to 1899 .

release of the database (release 8) contains 31182 entries (records) on landslides and 8518 entries on flooding events. The AVI module also contains a bibliographical database listing 2027 references used to compile the historical archive.

The GIANO module contains information on single or multiple landslides, inundations and snow avalanches occurred in Italy in the 18th and 19th centuries, including the original sources of information. The module was obtained from a larger archive compiled in the eighties by SGA Storia Geofisica e Ambiente (http://www.sga-storiageo.it) for ENEA (the Italian energy research institute, http://www. enea.it) and aimed at collecting the effects of all natural disasters in Italy in the period from 1000 to 1900 . The information in the GIANO module covers the period from 1700 to 1899 and refers to 793 flooding events (of which 388 in the 18th century and 405 in the 19th century) and 356 landslide events (of which 56 in the 18th century and 300 in the 19th century). "Testimonies" (i.e. single entries) on landslides are 2132,884 in the 18th century and 1248 in the 19th century, and "testimonies" on floods are 528, 126 in the 18th century and 402 in the 19th century. SGA collected the historical information from 177 bibliographical references, including catalogues, repertoires, scientific reports and other historical sources. Figure 5 shows the geographical distribution of landslides and floods inventoried in the GIANO database.

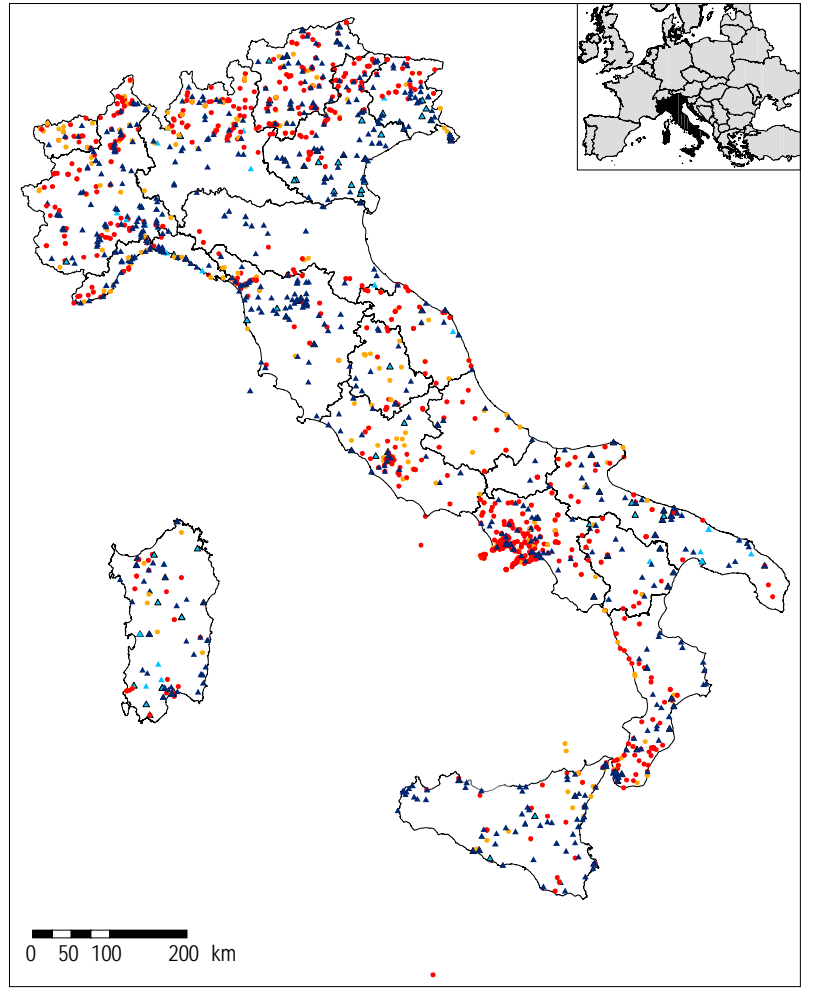

Fig. 6. FATALITIES module. Geographical distribution of landslides (triangles) and floods (dots) with casualties in the period from 1900 to 2002. Legend: red dot, landslide site with fatalities; yellow dot, landslide site with injured people; blue triangle, flood site with fatalities; light blue triangle, flood site with injured people.

The GIANO module lacks the completeness and accuracy of the AVI database, mostly due to the difficulty in collecting information from historical sources and testimonies. Some duplication of information exists with the AVI database. As an example, historical landslides in the catalogues compiled by Almagià in 1907 and 1910 are listed in both databases. Despite these limitations, GIANO is a major contribution to the SICI information system. It extends the breath of the AVI database to the 18th and 19th centuries and it provides a multi-secular perspective on the extent of landslides and floods in Italy.

The FATALITIES module contains information on landslides and floods which have resulted in deaths, missing persons, injured people, evacuees and homeless people in Italy, in the 724-years period between 1279 and 2002 (Guzzetti, 2000; Guzzetti et al., 2004). Non systematic information on snow avalanches with human consequences is also listed in the database. The module lists 4534 records, of which 2379 on landslides and snow avalanches with human consequences and 2155 on floods that resulted in damage to people. Figure 6 shows the geographical distribution of landslide and flood sites with casualties in Italy in the period from 1900 to 2002 .

The ABPO module contains information on landslides and floods in the Po River basin, the largest watershed in Italy 


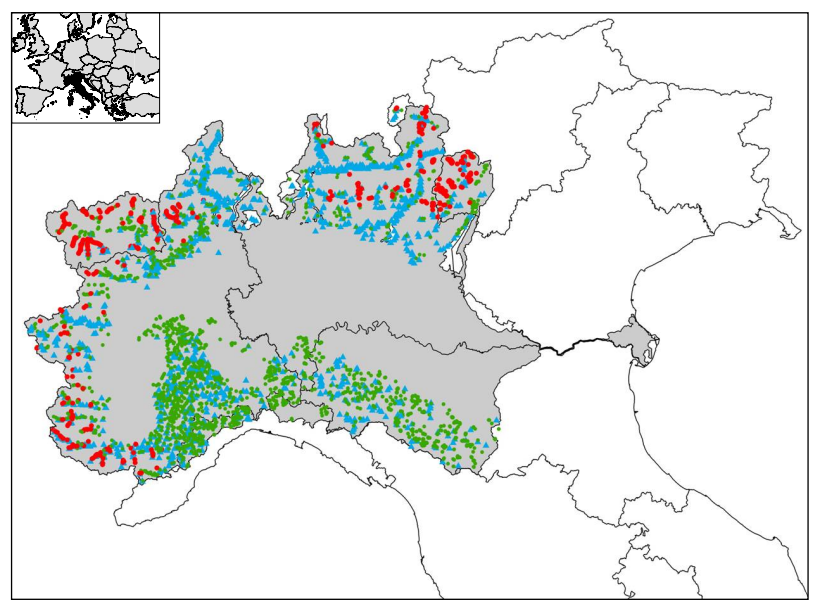

Fig. 7. ABPO module. Geographical distribution of landslides (green triangles), floods (blue dots), and snow avalanches (red dots) that have interfered with structures and the infrastructure in the Po River basin in the period from 1300 to 1995.

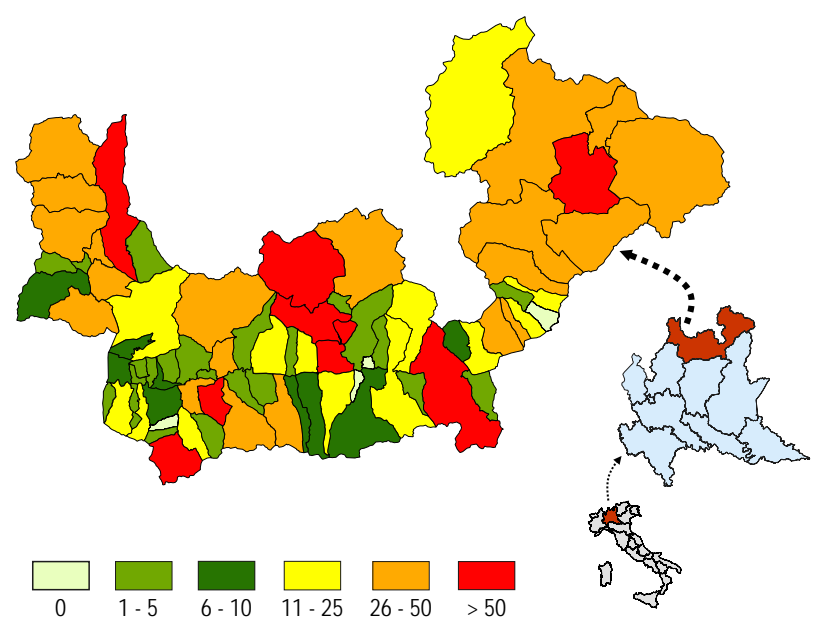

Fig. 8. LOMBARDY module. Map showing municipalities in the Sondrio province, Lombardy region. Municipalities are coloured based on the number of information on landslide (including debris flows) and flood events in the period from 500 to 1993.

$\left(74970 \mathrm{~km}^{2}\right)$. The Po River Basin Authority collected the information on historical floods, mass movements and snow avalanches from a variety of sources, including historical and archive documents that span the period from 1300 to 1995. The River Authority collected the historical information as an aid to the preparation of the watershed master plan (http://www.abpo.it/piano/Pai/indice.htm). The ABPO module contains 4171 records, listing 5990 sites affected by 1647 floods, 1995 landslides and 536 snow avalanches (Fig. 7). Information on the type and extent of damage caused by inundations, slope failures and show avalanches is available for a few sites. Inspection of Fig. 7 reveals that only the events that have occurred in the mountains and in the hilly part of the river basin are considered. Flooding events which have

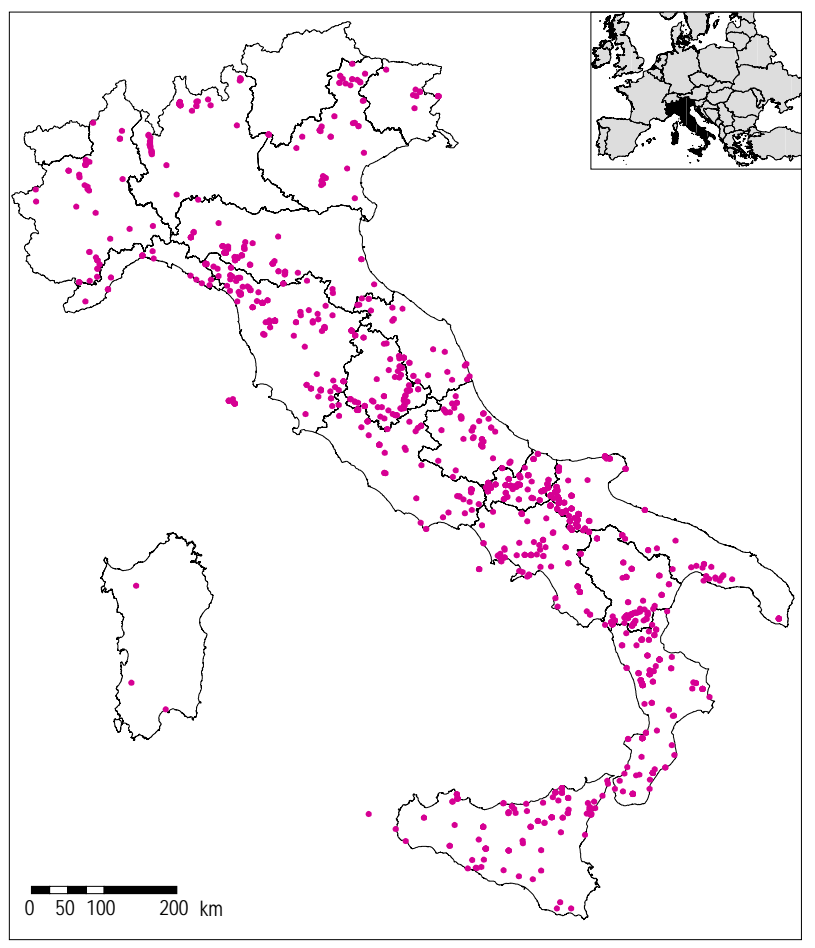

Fig. 9. DPC module. Geographical distribution of the municipalities where technical surveys aimed at determining the landslide and flood hazard and risk were performed by CNR GNDCI scientists in the period from 1990 to 2000 .

occurred in the Po plain, along the Po River and its major tributaries (cf. Fig. 2) are not listed in the database.

The LOMBARDY module contains information on 3765 landslides, debris flows and flooding events in Valtellina and Val Chiavenna, two Alpine valleys in the Sondrio province (Lombardy, northern Italy), in the period from 500 to 1993 (Fig. 8). The historical database contains 2948 records, listing information obtained by systematically searching 590 bibliographical references and historical documents, which were found in local archives by Govi and Turitto (1994). LOMBARDY is presently the only module of the SICI information system that contains information on landslides and floods which occurred on a relatively small $\left(3200 \mathrm{~km}^{2}\right)$ geographical area, and that was obtained through a very detailed and systematic analysis of all the available historical sources. LOMBARDY is a valuable addition to the SICI information system because it provides a measure of the quantity and quality of information that can be expected from an accurate and systematic search of historical information in the Alps.

The DPC module contains information and documents on 1389 local surveys and technical activities performed by CNR GNDCI experts and scientists in the period between 1990 and 2000. The investigations were requested by the Mayor of a municipality or the Prefect of a province, and were conducted on behalf of the National Department of Civil Protection (DPC) to investigate landslides and floods that posed an imminent threat to the population. The DPC 


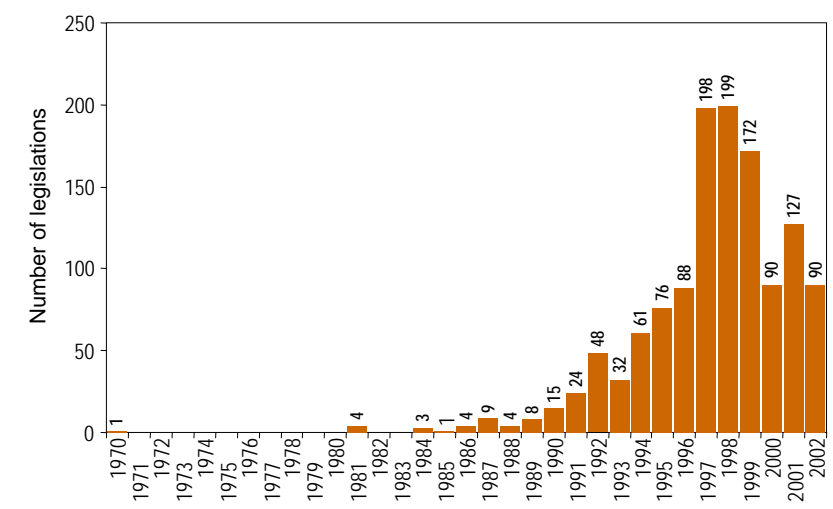

Fig. 10. LAWS module. Number of legislations in Italy on hydrological and geomorphological hazards in period from 1970 to 2002.

module lists 1231 surveys in 578 municipalities (Fig. 9) and contains 639 documents, reports, maps and photographs (as PDF files), including 269 survey reports, which included a description of the event, the type and the extent of damage, and indications on remedial measures to locally mitigate the landslide and flood risk.

The LAWS module is the last entry to the SICI information system, and contains information and documents (as PDF files) on Italian laws, decrees, and ministry orders on hydrological and geological hazards (Fastelli, 2003a). The database covers the period from 1970 to 2002 , and lists 1255 legislative acts (Fig. 10).

The REFERENCES module is a collection of bibliographical and reference catalogues, including the AVI project main reference list (AVI, 2027 references), the catalogue of 2800 publications, maps, and reports published or edited by CNR GNDCI (GNDCI, Fastelli, 2003b), the list of books and reports in the IRPI library in Perugia (IRPI, 1500 references), the bibliographical catalogue prepared by Guida et al. (1979) for the period from 1900 to 1978 (ITALYREF, 940 references), and the catalogue of the national and international literature on landslides and related topics compiled by the IRPI Applied Geology Group (INTEREF, 3140 references). Figure 11 shows the yearly distribution of references in the period from 1900 to 2002.

The DISCHARGE and SEDIMENT modules contain data on daily water discharge and on daily sediment yield. Measurements of mean daily water discharge are available for 111 gauging stations in central Italy (Fig. 12), in the period from 1929 to 1996 . The data were digitized in the early nineties by the Faculty of Agriculture of the Perugia University, and were obtained from the annual reports (Annali Idrologici, parte II) published by the National Hydrographical and Oceanographic Service (Servizio Idrografico e Mareografico Nazionale). Data on sediment yield are available for 117 stations (Fig. 12) and cover (non systematically) the 68year period from 1929 to 1996.

Access to the AVI, GIANO, ABPO, LOMBARDY, LAWS and DISCHARGE modules is available trough the

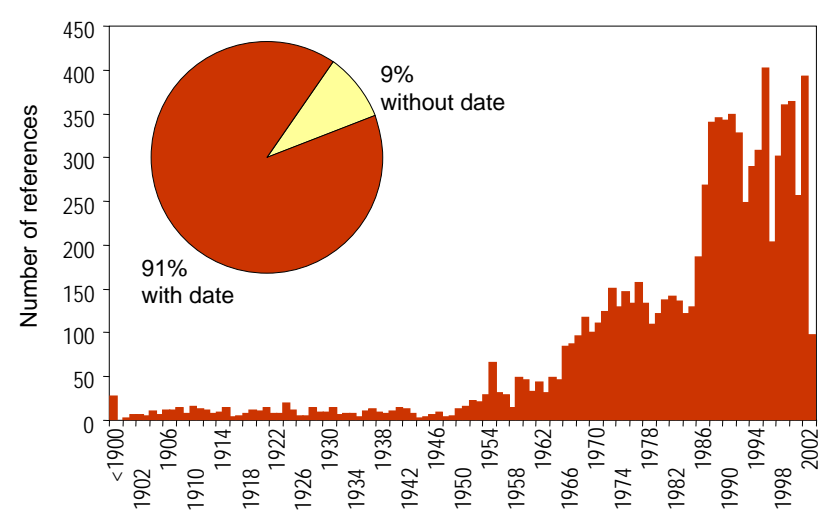

Fig. 11. REFERENCES module. Number of references on landslides and floods stored in the various bibliographical catalogues in the period from 1900 to 2002 .

SICI home page (http://sici.irpi.cnr.it). Access to the FATALITIES, DPC and SEDIMENT modules is restricted. Bibliographical information stored in the REFERENCES module is partly available to the public trough the SICI home page and partly restricted to selected users.

\section{Hardware and software configuration ${ }^{1}$}

The hardware and software configuration of the SICI information system has changed significantly over the time, to adjust to new and more abundant data, to respond to the requests of new users, and to exploit the new technologies that have become available. In this section, we describe the evolution of the software we have used and we present the current hardware and software configuration.

\subsection{The history}

In 1990-1992, during the main phase of the AVI inventory, information was collected in digital format using simple software developed using DBU, a public domain tool capable of writing files in the Bordland $\odot$ dBase ${ }^{\circledR}$ format (DBF III). CNR IRPI developed a specific database managing system (DBMS) with a graphical (and geographical) interface to store and manage the information. The program was written for Microsoft ${ }^{\circledR}$ Windows 3.0๑ in the $\mathrm{C}$ language, and supported DDE (digital dynamic exchange), allowing for dynamic links with other software. In a pioneering attempt to deliver the historical information collected by the AVI project through the Internet, in 1993, in cooperation with the Computer Centre of the University of Perugia, we developed a system based on WAIS, a non-relational database publicly available under the Unix operative system. Specific software allowed to perform simple, text based queries to the WAIS database and formatted the output using Hypertext Markup

\footnotetext{
${ }^{1}$ Use of trade, product or firm names is for descriptive purposes only and does not imply endorsement by CNR, GNDCI, IRPI or the authors.
} 


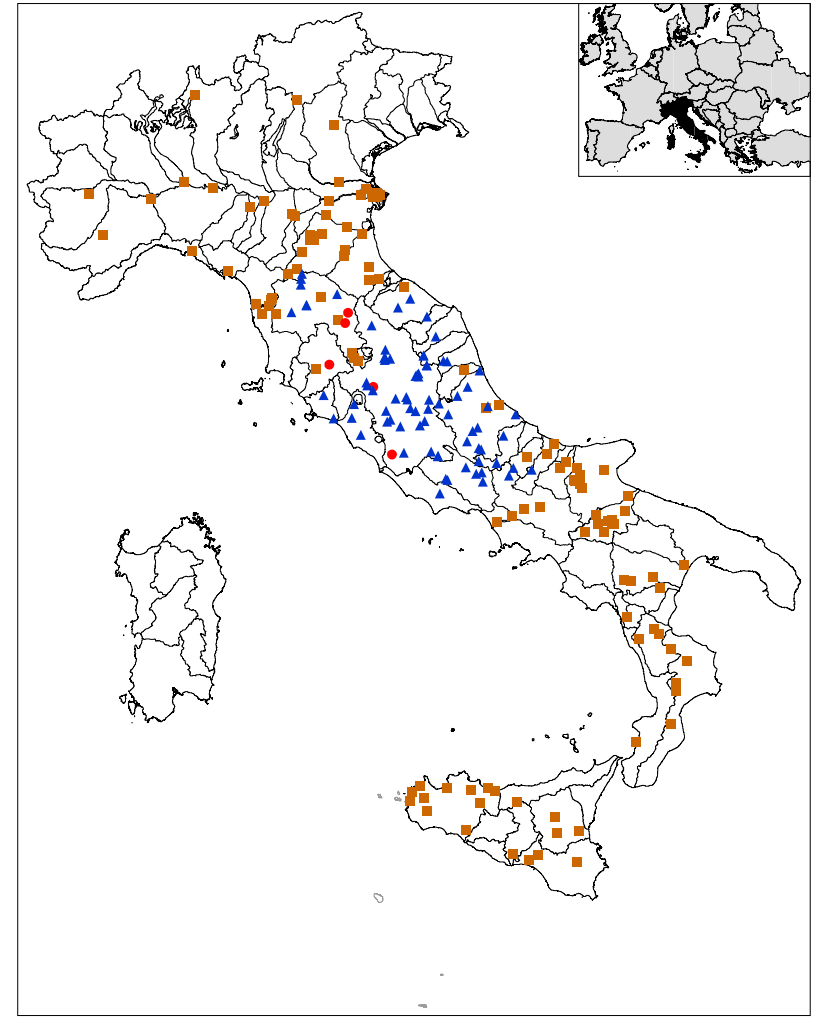

Fig. 12. Geographical distribution of gauging stations for which data are available in the DISCHARGE and SEDIMENT yield modules. Legend: blue triangle, water discharge gauging station; orange square, sediment yield gauging station; red dot, water discharge and sediment yield gauging station.

Language (HTML). HTML pages were displayed using the Internet browsers available at the time (i.e. Mosaic $\odot$ and Netscape $(\odot$ release 1.0$)$.

In order to exploit the inherent relational structure of the AVI database, in 1994-1995 we moved the data from the "flat" structure supported by WAIS, into a relational, commercial database management system (Sybase ${ }^{\circledR}$ SQL Server, running on a $S U N \circledast$ workstation). Specific software was written to query the DBMS and to format the output as HTML files (Potenza et al., 1998). Images, simple raster maps and hyperlinks were added to the HTML files, making the "navigation" into the AVI database more efficient. To facilitate the editing and the correction of the information stored in the database, the relational structure of the DBMS was mirrored in the Microsoft Windows environment, using Microsoft Access 95○. The migration facilitated the addition of the new information collected during the archive updates. Writing and maintaining the software used to query the DBMS was cumbersome and error prone. In addition, the software did not fully exploit the transact SQL language used by Sybase to query the DBMS. To overcome these limitations, in 1996 we adopted Sybernet $\odot$ a software written by D. D. Workman (at the Stanford Research Institute, http://sybernet.sri.com/). Sybernet is a stand alone CGI dae-

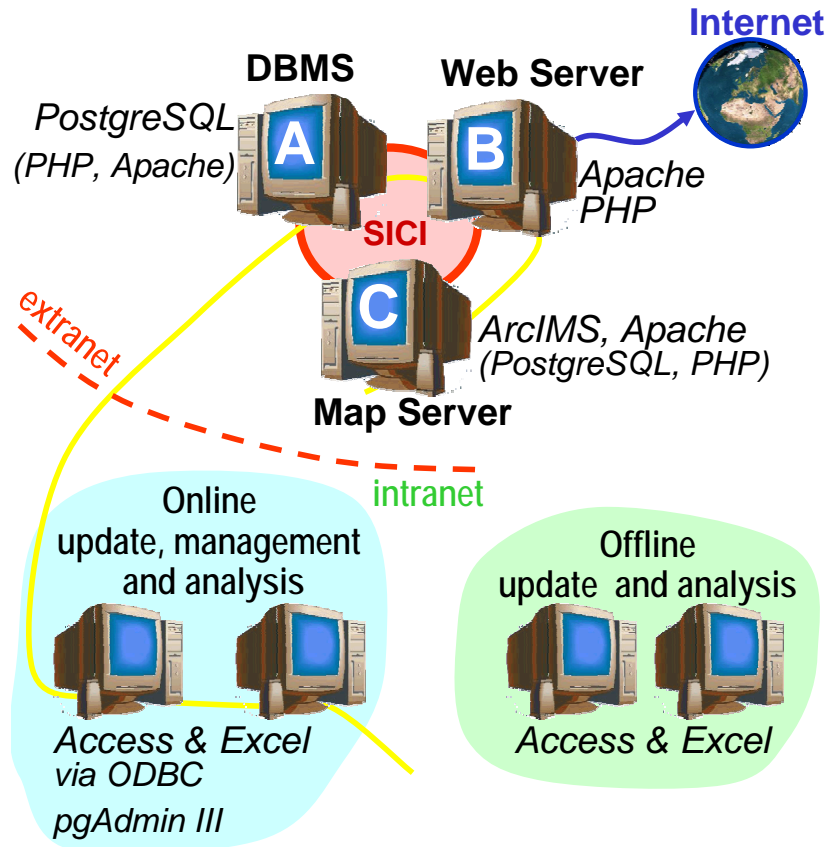

Fig. 13. SICI hardware and software configuration. Use of trade, product or firm names is for descriptive purposes only and does not imply endorsement by CNR, GNDCI, IRPI or the authors.

mon which holds connections to the Sybase SQL server on behalf of a web client, and is capable of submitting standard SQL queries to the Sybase SQL server and to format the output as HTML pages.

\subsection{Current setting}

In 1999, in the attempt to cut the costs of the hardware and software maintenance fees, we changed DBMS. We decided to use chiefly software with an "open source" license agreement. We selected PostgreSQL® (http://www. postgresql.org/) as the new DBMS, we adopted PHP $\odot$ (http: //www.php.net/) as the standard language to query the DBMS and to format the output, and we implemented Apache ${ }^{\circledR}$ (http://httpd.apache.org/) as the web-server software used to publish the information on the Internet.

Figure 13 portrays the current hardware and software configuration used in SICI. The information system is based on a cluster of three personal computers running Linux ${ }^{\circledR}$. The first computer (A in Fig. 13) hosts the PostgreSQL $\AA$ DBMS, including the data and the documents available for delivery, as PDF files. A second computer (B in Fig. 13) is the main web server, receiving the queries from the users, interrogating the DBMS via PHP, and formatting and delivering the results as HTML pages. The third computer (C in Fig. 13) runs a GIS-based web server, which allows publishing geographical information, including interactive maps, on the web. For this purpose, we currently use Esri® ArcIMS $\odot$ software. Figure 14 shows examples of maps published by the SICI Map Server. Figure 14A portrays the geographical distribution 

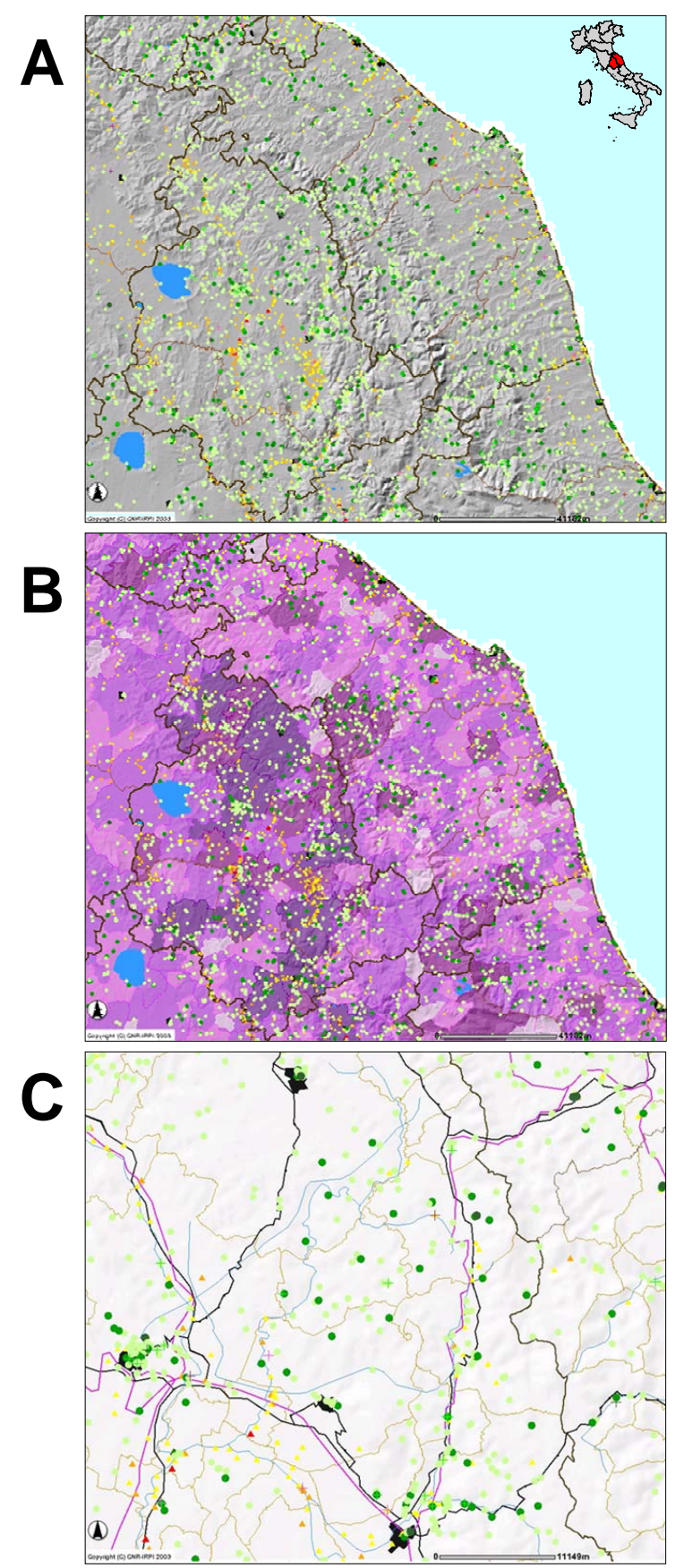

Fig. 14. Examples of maps published by the SICI map server (http: //sicimaps.irpi.cnr.it). (A) Map showing sites affected by landslides (green dots) and floods (blue triangles) in the Umbria and Marche regions, central Italy. (B) Map showing the number of landslide and flood events in the municipalities of the Umbria and Marche regions. Darker colours indicate a larger number of events. (C) Enlargement of map A. Legend: 1 landslide event (light green), 2 or more landslide events (dark green), 1 flood event (yellow triangle), 2-9 flooding events (orange triangle), 10 or more flooding events (red triangle), municipality boundaries (light brown), major roads (black line), railways (violet line), main rivers (light blue line), and main urban areas (black polygon). of sites affected by landslides and floods in the Umbria and Marche regions of Central Italy, and Fig. 14B shows, for the same geographical area, the municipalities coloured based on the number of landslide and flood sites in each municipality. We have built a level of redundancy into the information system, to cope with possible hardware and software failures. Host A runs PHP and an independent Apache ${ }^{\circledR}$ web-server, and can serve user requests autonomously. Host $\mathrm{C}$ contains a replica of the PostgreSQL DBMS, including data and documents, and can replace host A if necessary.

Figure 13 also shows how we manage, maintain, and update SICI. We maintain the DBMS from personal computers running pgAdmin $\odot$ III, a software that connects directly to PostgreSQL and allows to manage the databases, tables, records, fields and users. We update and manage data stored in the information system from personal computers running Microsoft Access or Microsoft Excel software, which interacts with PostgreSQL via ODBC. We digitize most of the new data, catalogues and documents off-line, using chiefly Microsoft Access or Microsoft Excel software. When ready, new releases of an entire database or of individual tables are uploaded into the information system.

\section{Applications}

The historical information on landslides and floods stored in the SICI information system is used for a variety of scientific, technical, and legal applications. The Italian government recognized the relevance of the AVI database. Following the massive landslides in Sarno, Campania, of 5 May 1998, Law 267 of 1998 on landslide and flood risk assessment procedures specifies that the AVI database is a mandatory source of information for the assessment of landslide and flood hazards and the associated risk in Italy. Regional governments, river basin authorities and municipalities used the AVI database to ascertain landslide and flood hazards. Research scientists, geologists, engineers and planners, civil protection personnel and concerned citizens access the SICI home page every day.

Guzzetti et al. (1994) compared the geographical distribution of landslide sites in the Umbria and Marche regions in centrally Italy, with a medium-scale landslide inventory map produced through the interpretation of medium-scale aerial photographs. The authors found that sites historically affected by slope failures were more abundant in the areas where landslide density was higher. Reichenbach et al. (1998) combined the historical record of landslides and floods in the Tiber River basin, central Italy, with measurements of mean daily discharge at significant gauging stations in the catchment. The comparison allowed establishing hydrological thresholds for the occurrence of landslides and floods in the Tiber River basin. Guzzetti (2000) used the AVI archive and other sources of historical information to compile a catalogue of landslides with human consequences in Italy, from 1279 to 1999. Guzzetti et al. (2004) revised and updated the catalogue of Guzzetti (2000) and compiled 
a similar catalogue for floods with human consequences in Italy. Guzzetti (2000) and Guzzetti et al. (2004) used information on landslides and floods that caused deaths, missing persons and injured people to ascertain individual and societal landslide and flood risk in Italy in the 20th century.

In the following, we present four new applications based on the historical catalogue of landslide and flood events in Italy from 1900 to 2002, obtained from the main AVI database.

\subsection{Geographical distribution of landslides and floods}

We use the catalogue of landslide and flood events obtained from the AVI database to study the geographical distribution of sites damaged by landslide and flood events in Italy, in the period from 1900 to 2002 (Fig. 2). The catalogue lists the exact or the approximate location of 21159 sites affected by 32162 landslide events and of 15904 sites affected by 29233 flooding events. Comparison of the geographical distribution of the damaged sites with the administrative boundaries reveals that all the 103 Italian provinces experienced recursively landslides or floods. Of the total number of 8103 Italian municipalities (in 1998), 4846 (59.5\%, covering 75\% of the territory) have experienced at least once a landslide, 4492 (55.1\%, covering $71 \%$ of the territory) have experienced at list once a flood, and 6475 (79.9\%, covering $91 \%$ of the territory) have experienced both landslides and floods. The 1638 municipalities (20.1\%, covering $9 \%$ of the territory) for which information on historical landslides or floods is not available in the AVI database are mostly small in size, or are located in remote and inhabited mountain areas or in the hinterland of large cities (e.g. Milan). In these municipalities, which cover about $9.5 \%$ of the Italian territory, landslides and floods may have occurred but they may have not been noticed. Alternatively, they may have been observed but quickly removed, or they may have not been reported because they did not cause damage. Figure 15 shows the density of damaging events in each municipality, i.e. the number of landslide (Fig. 15A) and inundation (Fig. 15B) events per $10 \mathrm{~km}^{2}$. These maps are available on line from the SICI map server (http://sicimaps.irpi.cnr.it). Similar maps can be prepared for the number of sites affected by landslides, floods or both.

\subsection{Seasonal distribution}

The historical catalogue of landslide and flood events reports the exact or approximate date (or period, in the case of events that lasted for more than one day) for the majority of the events listed in the catalogue. In particular, the catalogue lists 27679 (96.1\%) flood events and 19839 (61.9\%) landslide events for which the month of the occurrence is known, allowing for analysis of the seasonality of slope movements and inundations in Italy. Figure 16 portrays the number and percentage of landslide (green bars) and flood (blue bars) events. The monthly number and percentage of the events are shown from July to June, to delineate seasonality.

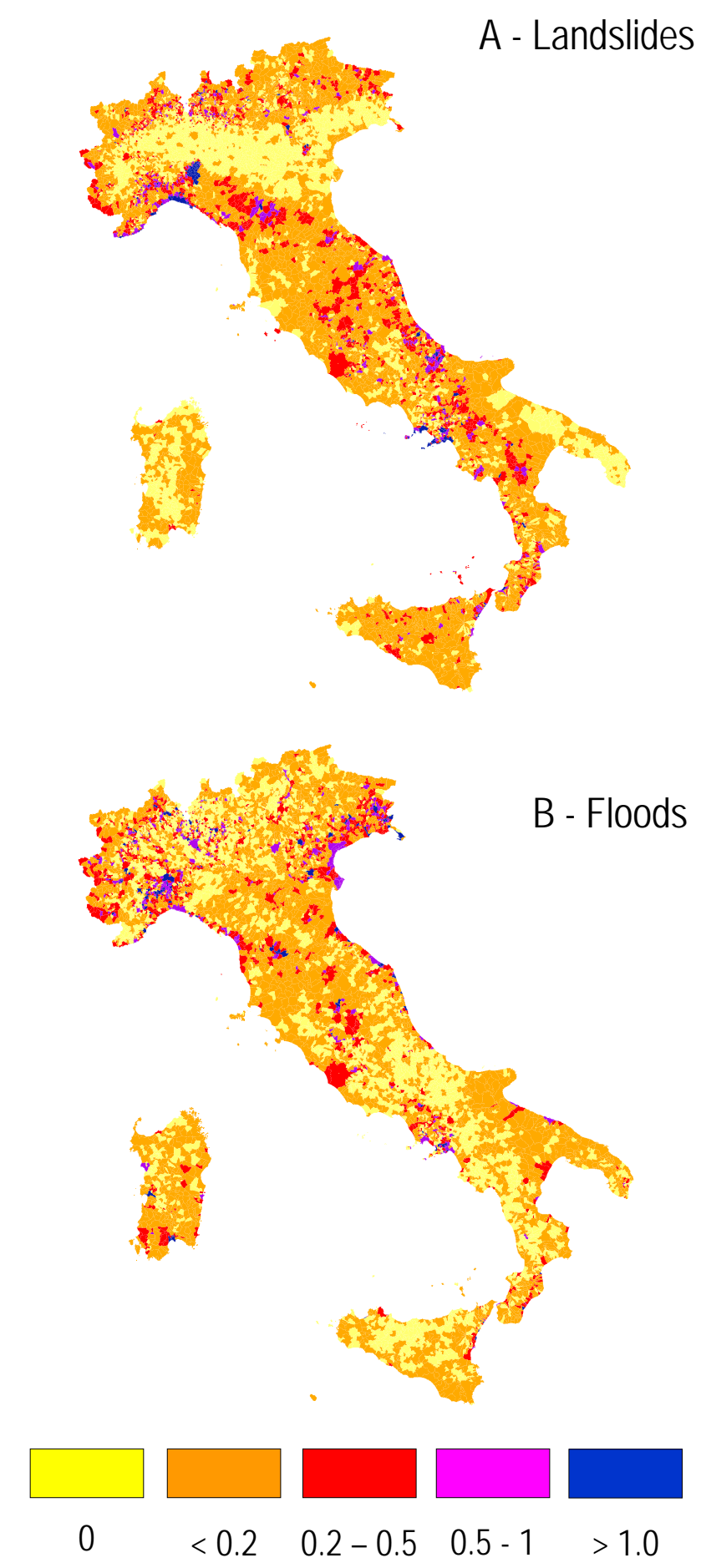

Fig. 15. Density of landslide (A) and flood (B) events in the 8103 Italian municipalities. Density is the number of events inventoried in the historical catalogue per $10 \mathrm{~km}^{2}$.

In Fig. 16, histograms $\mathrm{A}$ and $\mathrm{B}$ show data for the entire country. The largest number of inundations occurred in November $(19.8 \%)$, followed by October $(18.8 \%)$ and September (13.0\%), and the largest number of landslide events occurred in January (14.4\%), followed by November $(13.7 \%)$ and October (12.9\%). Inspection of the two graphs 

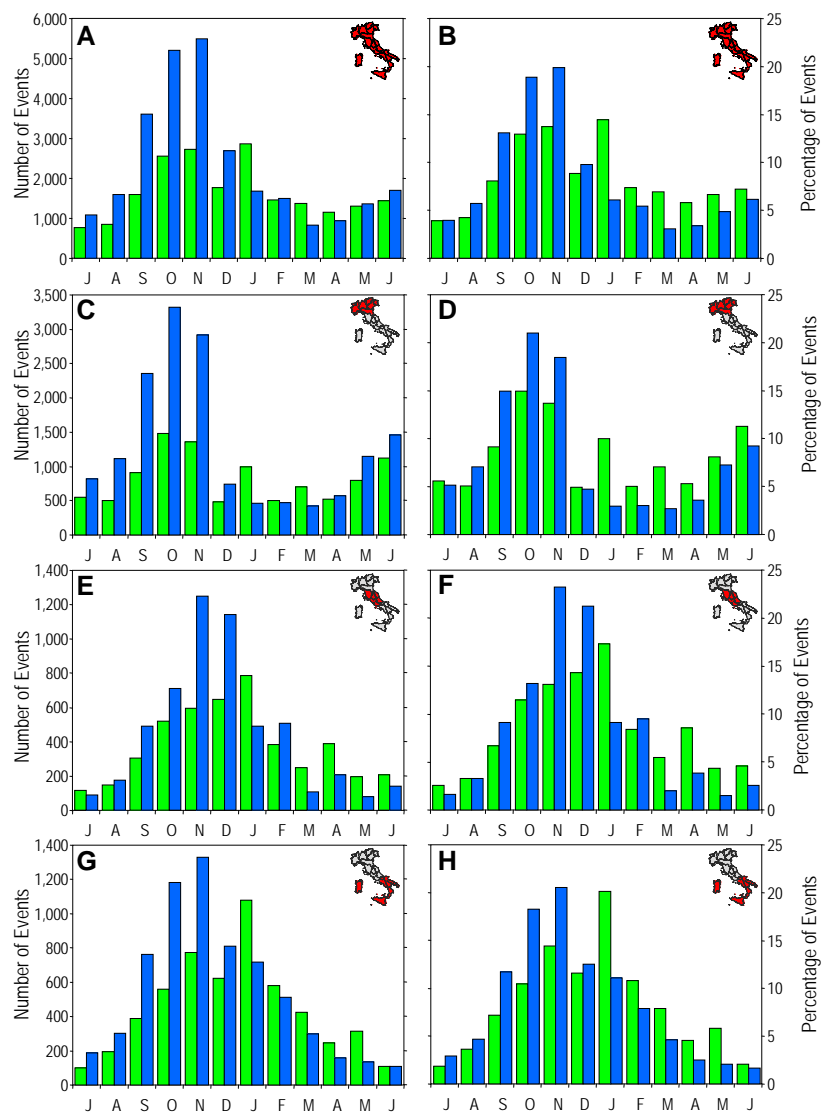

Fig. 16. Seasonal distribution of landslide (green bars) and flood (blue bars) events in Italy. Left graphs $(\mathbf{A}),(\mathbf{C}),(\mathbf{E}),(\mathbf{G})$ show the number of events; right graphs $(\mathbf{B}),(\mathbf{D}),(\mathbf{F}),(\mathbf{H})$ show the percentage of events. A and B, data for the entire country; $\mathrm{C}$ and $\mathrm{D}$, data for northern Italy; E and F, data for central Italy; G and H, data for southern Italy.

reveals a weak seasonality, with the majority of the landslides $(57.9 \%)$ and flood $(67.5 \%)$ events occurring between September and January. Seasonality is clearer for inundations and less evident for landslides, indicating a different behaviour of geomorphological and hydrological phenomena. Inundations are largely the direct effect of precipitation, whereas the occurrence of mass movements is also related to the antecedent conditions of the slopes. Also, the landslide catalogue lists a few slope failures which were not caused by a meteorological trigger (e.g., earthquakes).

By combining information on the month of occurrence of the events with their geographical location, we can investigate the variation of the seasonal distribution of landslides and floods in Italy. In Fig. 16, the histograms from $\mathrm{C}$ to $\mathrm{H}$ portray the monthly number and percentage of landslide and flood events in northern (C-D), central (E-F) and southern $(\mathrm{G}-\mathrm{H})$ Italy. Seasonality of landslide and flood events is more evident in central and southern Italy, and less evident in northern Italy. In northern Italy (Figs. 16C-D), floods are more abundant in the autumn, with the largest number of events recorded in October (21.0\%), followed by November
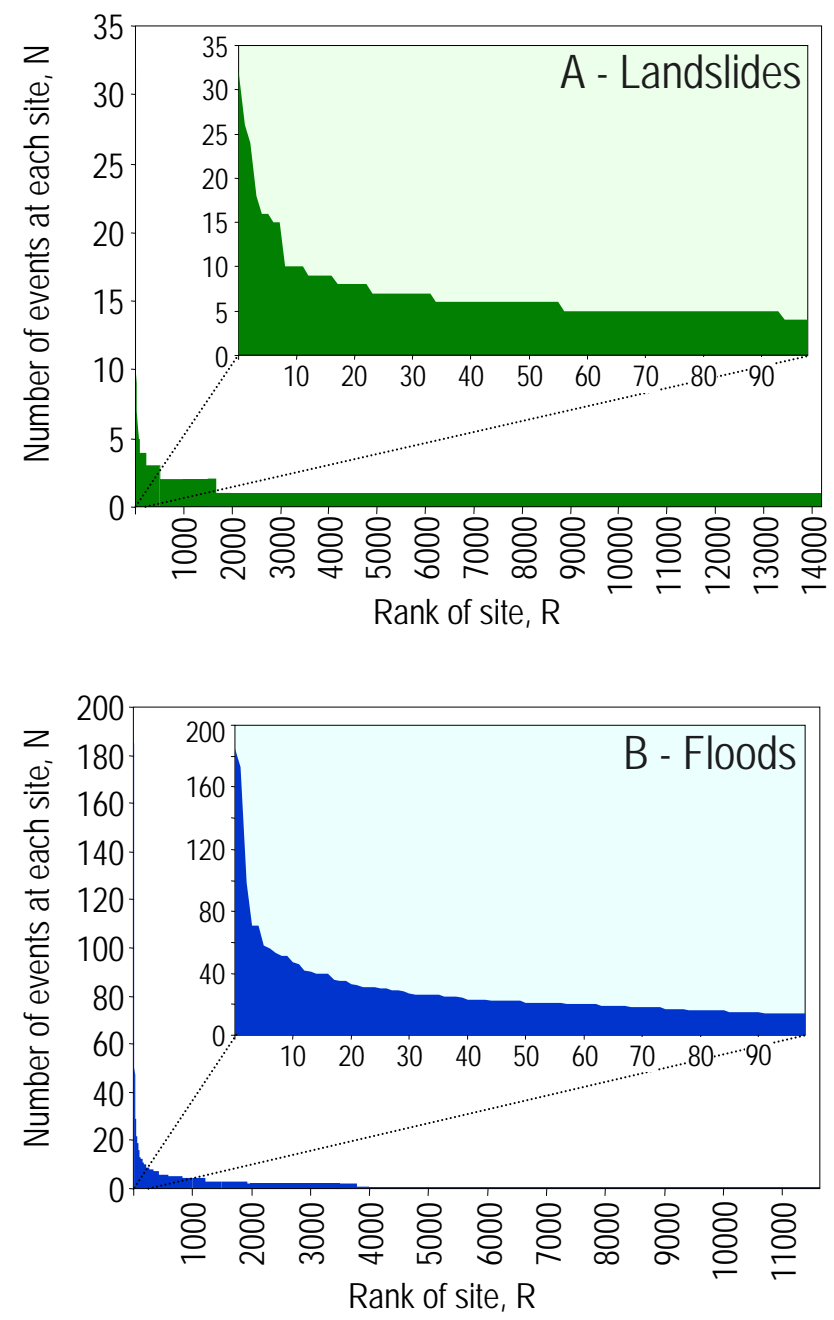

Fig. 17. Number of damaging events at each site. Linear scales. (A) landslide sites (green); (B) flood sites (blue).

(18.4\%) and September (14.9\%). Floods are also abundant in the spring, and particularly in June $(9.2 \%)$ and May (7.2\%). In northern Italy (Figs. 16C-D), landslides are more abundant in autumn, with $14.9 \%$ of the events occurring in October and $13.7 \%$ in November. In this geographical region mass movements are also abundant in June (11.3\%) and January $(10.2 \%)$. In central Italy (Figs. 16E-F) floods are most abundant in November (23.2\%) and December (21.2\%), with only few events occurring from March to August (14.8\%). In central Italy (Figs. 16E-F) slope failures are most abundant in January (17.3), followed by December (14.3), November (13.1), and October (11.5). In southern Italy (Figs. 16G-H) floods are most abundant in November $(20.4 \%)$ followed by October $(18.2 \%)$, with only few events occurring in the spring and the summer (18.3\%). In the same geographical area (Figs. 16E-F) landslides are most frequent in January (20.0\%), followed by November (14.4\%). Differences in the seasonal distribution of landslides and floods in the Italian regions reflect various meteorological regimes. 


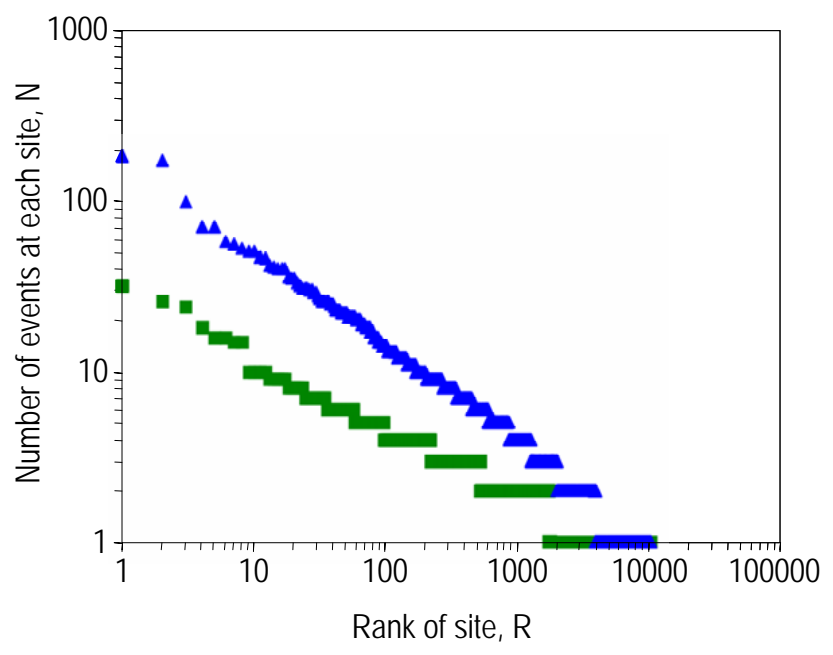

Fig. 18. Number of damaging events at each site. Logarithmic scales. Blue triangles, floods; green squares, landslides.

\subsection{Recurrence of damaging events}

Analysis of the historical catalogue reveals that many sites were affected by landslides or floods repeatedly (i.e. more than once) in the period from 1900 to 2002 . In Fig. 17 we plot the number of times each site was damaged (on the $y$ axis) against its rank (on the $\mathrm{X}$-axis). Inspection of the graphs reveal that total number of damaged sites is large for both landslides (14 231) and floods (11 645), confirming that inundations and landslides are widespread. Figure 17 also shows that sites more frequently damaged are relatively few. Of the 11645 flood sites $(86.3 \%)$ for which the geographical location is reasonably certain, $3790(32.5 \%)$ were affected two times or more, $824(7.1 \%)$ were affected five times or more, and only $195(1.67 \%)$ were affected ten times or more in the 103-year period from 1900 to 2002. During the same period, of the 14231 landslide sites $(89.2 \%)$ with a reasonably well known geographical location, 1668 (11.7\%) experienced two or more events, $94(0.66 \%)$ experienced five or more events, and only twelve $(0.08 \%)$ experienced ten or more events. The disparity between landslides and floods outlines a known different behaviour of the geomoprhological and hydrological processes. Inundations tend to repeat in the same place more frequently than mass movements, chiefly because of morphological constrains (Guzzetti et al., 1994; Reichenbach et al., 1998a). It should be noted that some of the peak values correspond to region or province chief towns, reflecting a known bias in the historical database toward inhabited or densely populated areas (Reichenbach et al., 1998a).

Figure 18 shows the same data portrayed in Fig. 17, but in $\log -\log$ scale. Inspection of Fig. 18 reveals that the relationship between the number of times each site was damaged and its rank is nearly linear for both landslides and floods, indicating a power-law (i.e. fractal) distribution. This suggests a self-similar scaling behaviour of the number of events at each site. However, the tails of the raw distributions are rather er-

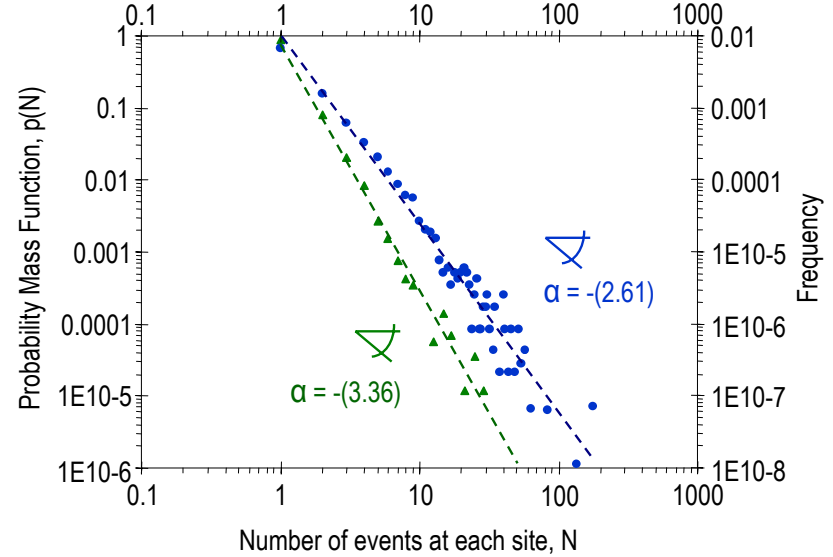

Fig. 19. Probability Mass Function (PMF) and frequency of events (events per year) at each site. Blue dots, floods; green triangles, landslides.

ratic. To get a better sense of the shape of the tails, we have estimated the distributions. We have accomplished this by applying a variable-width binning technique. The result is shown in Fig. 19 that portrays the probability mass function (PMF) and the frequency of events at each site, in the period from 1900 to 2002. In Fig. 19 the landslide and flood distributions exhibit a distinct linear (power-law) trend. However, the two distributions differ significantly in their slope, which indicates that their power-law scaling exponents differ. Analysis of the graph reveals that the probability of experiencing a large number of landslide events in the same site is about 10 to 100 times smaller than the probability of having the same number of inundation events, confirming that flooding is a much more concentrated (i.e. geographically stationary) phenomena than landsliding, which is more widespread and spatially distributed.

The information on the number of events at each site allows for computing the rate of landslide and flood events in the 8103 municipalities in Italy. We compute the rates of events by dividing the total number of landslide events in each municipality by the time span of the catalogue (i.e. 103 years). Assuming that landslide and flood rate will remain the same for the future (a strong assumption) and adopting a Poisson probability model, we can determine for different time intervals the exceedance probability of experiencing one or more damaging landslide or flood in each municipality (Coe et al., 2000). Figure 20 and Table 1 show the exceedance probabilities for $5,10,25,50$ and 100 years. For a 5-years period, only 120 municipalities $(1.9 \%)$ have a 0.90 or larger probability of experiencing at least one damaging landslide or inundation, and 753 municipalities $(11.7 \%)$ have a 0.50 or larger probability of experiencing at least one landslide or inundation. These figures increase to $382(5.9 \%)$ and $1689(26.3 \%)$ municipalities for a 10 -years, to $1319(20.5 \%)$ and $3835(59.6 \%)$ municipalities for a 25 -years period, and to o $2621(40.7 \%)$ and $4783(74.4 \%)$ municipalities for a 
Table 1. Probabilities of experiencing one or more landslide or flood in a municipality. Based on the rate of occurrence of landslide and flood events in the 103-years period between 1900 and 2002. Historical information on landslide and flood events is available for 6432 of the 8103 Italian municipalities. Columns indicate, for six different time intervals, the number (N.) and the percentage (\%) of municipalities that exceed a given probability.

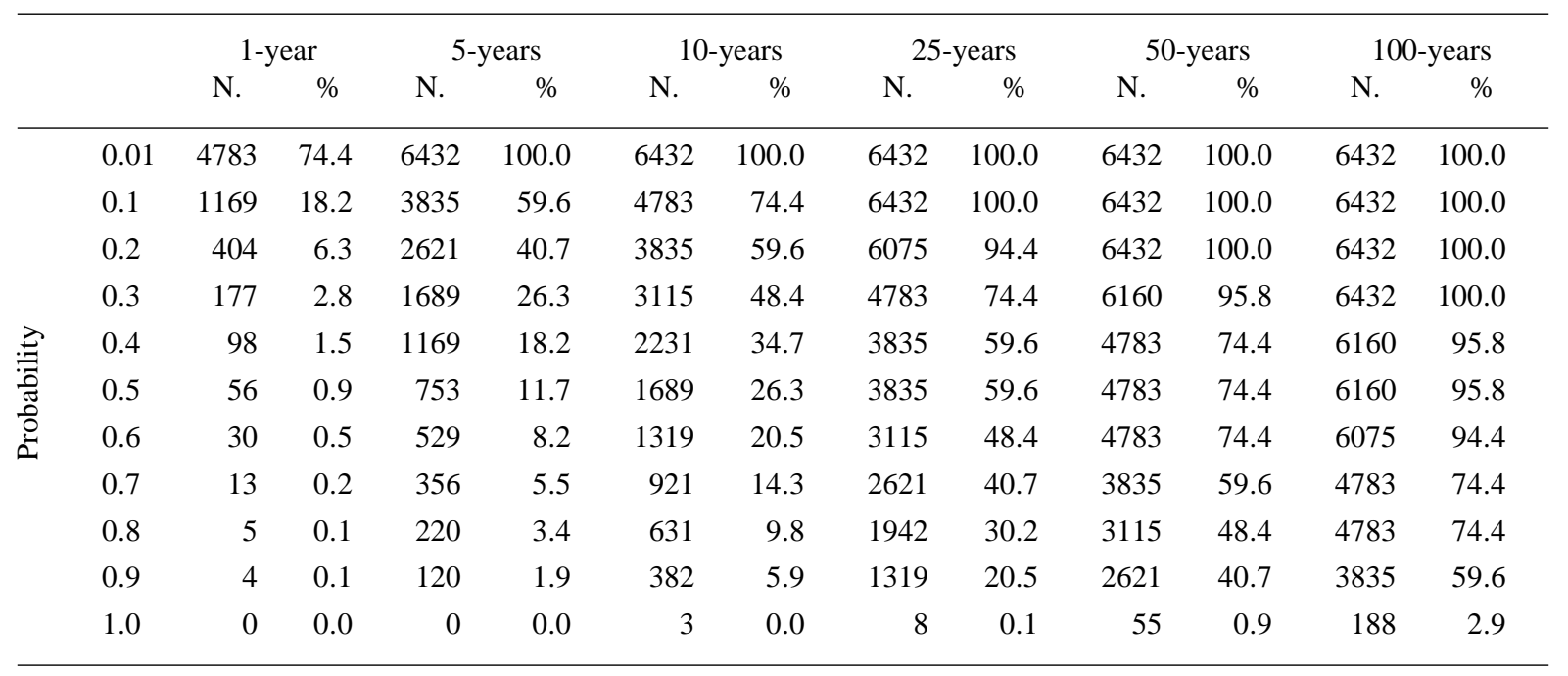

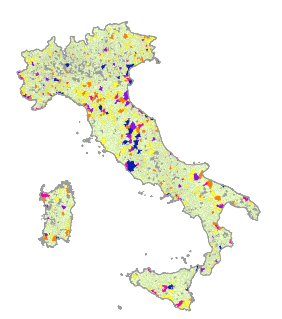

5 years
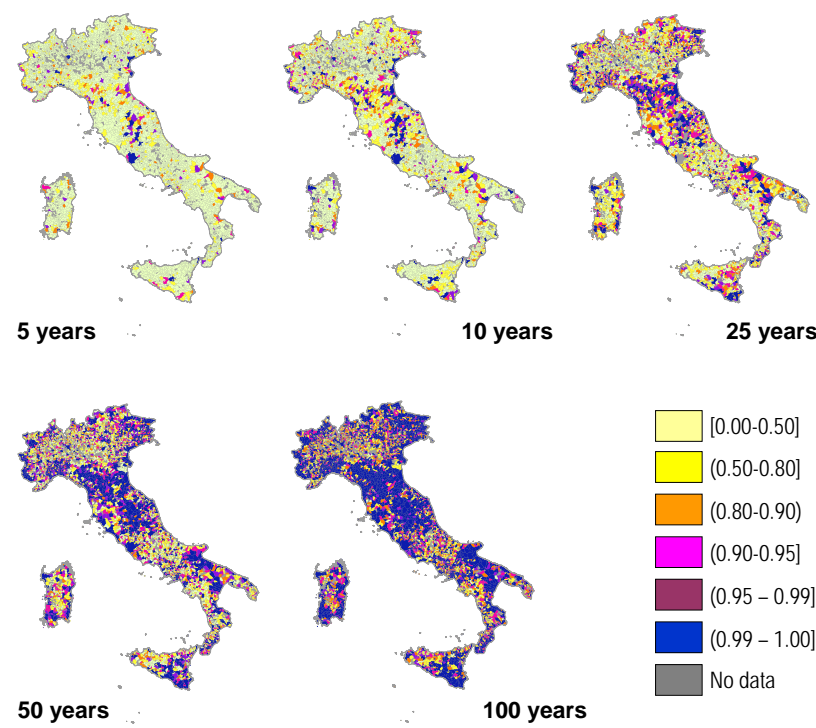

Fig. 20. Maps showing annual exceeding probabilities of damaging landslide and flood events in the 8103 Italian municipalities. Probability computed based on available historical information for the 103-years period between 1900 and 2002.

50 -years period, respectively (Table 1). For a 100-years period, 3835 municipalities (59.6\%) have a 0.90 or larger probability of experiencing at least one damaging landslide or inundation, and 6160 municipalities $(95.8 \%)$ have a 0.50 or larger probability of experiencing at least one slope failure or inundation. Despite the known and clear limitations of adopting a Poisson probability model to predict the occurrence of future landslides and floods based on the past rate of occurrence of damaging events (Coe et al., 2000; Crovelli,
2000; Guzzetti et al., 2003), Fig. 21 provides a quantitative (synoptic) estimate of landslide and flood hazards in Italy.

\subsection{Hydro-geomorphological events}

For single landslides and floods there is no clear measure of their magnitude. This is a limitation because frequency-magnitude relationships, similar to the well known Gutenberg-Richter (1954) relation linking the frequency and magnitude of earthquakes, cannot be established. Most of the landslides and floods stored into the historical catalogue are climatically induced, i.e. they were caused by individual meteorological events. We argue that a first order measure of the magnitude of a meteorological event resulting in landslides and floods is given by the number of sites damaged by landslides and floods.

For risk assessment purposes, it is of interest to analyze the effect (i.e. the impact) produced by meteorological events. In order to achieve this, we grouped together all the floods and landslides triggered by the same event, and we treated each grouping as single, distinct event, which we call "hydro-geomorphological" event. To obtain a catalogue of the hydro-geomorphological events we first combined the historical databases of landslides and floods. After the two databases were merged into a single catalogue, information on landslides or floods was sorted by date and by geographical location (i.e. region, province and municipality). Individual floods and landslides were grouped into hydrogeomorphological events based on the date (or the period) of occurrence and the geographical location. We obtained in this way a list of 4541 hydro-geomorphological events that have resulted in landslides or floods in the period between 1900 and 2002. 
The catalogue of hydro-geomorphological events can be investigated analysing the rank order statistics. In Fig. 21A we plot the magnitude of the hydro-geomorphological events, measured by the number of affected sites, against its rank, from largest to smallest. The relationship is nearly linear on the log-log plot, which indicates that it is approximately power-law distributed. Hydro-geomorphological events in the catalogue lasted from one to several (up to 25) days. Figure 21B portrays the number of hydro- geomorphological events against their length, in days. Again, the relationship is nearly linear on the log-log plot, suggesting a self-similar behavior. More systematic efforts to properly classify the events and their consequences are underway.

\section{Concluding remarks}

In many scientific disciplines, there are large scale efforts to build comprehensives information management systems. Some of these information systems store geographical and thematic data on natural hazards, including historical information. Under the assumption that damaging natural events will occur in the future in the same or in similar circumstances that lead to past events (a consequence of uniformitarianism, an accepted principle in geology and in natural hazard assessment), historical information on past events is a valuable aid to landslide and flood hazards assessment and in the design of mitigation strategies at various scales.

Historical data and information can be used: (a) to investigate the physical properties of natural events, such as landslides and floods, including the rate of occurrence and the possible changes in the rate, (b) to understand the effects of the natural hazards on the population, the structures and the infrastructure, including the assessment of individual and societal risk, and, (c) to validate heuristic, statistical or physical models of landslide and flood hazards and risk. Indeed, the only way a hydrological or geomorphological prediction (i.e. a flood forecast or a landslide hazard assessment) can be fully validated (i.e. proved correct or faulty) is through time. Practical, societal, economical and ethical considerations largely limit the time available for model testing and calibration. Historical information, even with large uncertainties, allows for a "backward" validation, or falsification, of predictive (i.e. "forecasting") models.

In this paper we have presented the results of an attempt to collect, organize, analyze and disseminate historical information on landslides and floods in Italy. In the past fourteen years we have collected a wealth of information on individual landslides and floods and on meteorological and seismic events that resulted in abundant slope failures and inundations. This information represents the core of SICI, the Italian information system on hydrological and geomorphological catastrophes. The information system also contains information and data on damage caused by mass movements and inundations, on daily discharge measurements and solidtransport measurements at selected gauging stations, bibliographical and reference information on landslides and inun-
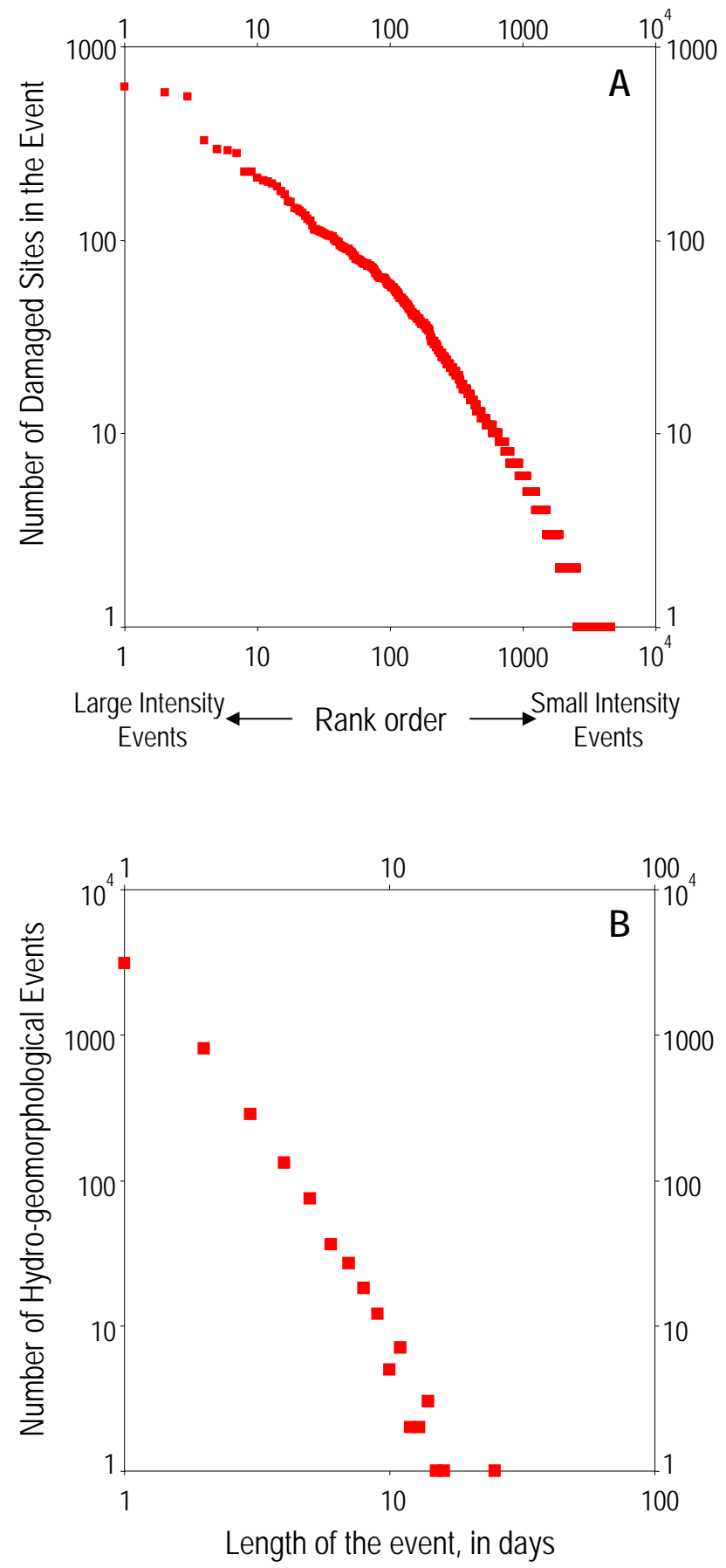

Fig. 21. Catalogue of hydro-geomorphological events (see text for explanation). (A) magnitude of the hydro-geomorphological events measured by the number of damaged sites (y-axis), against the site rank (x-axis). (B) Number of hydro-geomorphologic events against their length, in days.

dations, and a catalogue of national legislation on hydrological and geological hazards and risk in Italy.

After a description of the ten databases and digital catalogues currently present in the SICI information system, we have presented four recent applications of the data stored in the historical databases. The applications included: (a) the 
assessment of the geographical distribution of landslide and flood events in the 8103 Italian municipalities, including the production of maps portraying the density of events and of damaged sites in each municipality, (b) the assessment of the seasonal abundance of landslides and floods in different parts of of Italy, (c) the investigation of the recurrence of damaging events at each site and in each municipality, including an estimate of the probability of experiencing damaging events in the future, and d) an attempt to characterize the frequencymagnitude statistics of the triggering meteorological events that result in landslides and floods in Italy.

These are only a few of many possible applications of the historical information and thematic data stored in the SICI information system. Exploitation of this information has begun, and we believe it will represent a valuable help to understand natural hazards and to mitigate the undesired effects In Italy.

\section{Appendix A \\ Major flood and landslide disasters in Italy in the period from 1950 to 2000}

- 18 November 1951. Following prolonged and intense rainfall in the Alps and the Northern Apennines, the Po River broke the left banks at Occhiobello, Malcantone and Paviole (Polesine, Rovigo Province, northern Italy) causing the largest inundation of the 20th century (http://www.polesine.com; http://www.alfiumepo. it; http://www.deltapo.it). Water inundated the city of Rovigo, several towns (including Adria, Loreto and Cavarzene), and about $980 \mathrm{~km}^{2}$ of mostly farmland in 38 municipalities. The toll amounted to 138 casualties (including 123 deaths, 7 missing persons and 8 injured people), at least 140000 evacuees and homeless people, 52 bridges destroyed, 1200 houses and 9000 farming structures damaged or destroyed, and as many as 13000 farm animals lost, together with 100000 tons of wheat, and 21000 hectares of farmland (Catenacci, 1992). The inundation occurred in an area already economically very poor, forcing the population to immigrate to other Italian regions.

- 25-26 October 1954. Muddy debris flows triggered by high intensity rainfall inundated the city of Salerno (Campania, southern Italy) and five neighbouring towns (i.e. Cava dei Tirreni, Maiori, Minori, Tramonti and Vietri) causing extensive damage. The toll amounted to 318 deaths and missing persons, 157 injured people, and as many as 5466 evacuees and homeless people. Roads and the railway connecting Naples to the south of Italy were disrupted at several locations (Catenacci, 1992; Vallario, 2001).

- 9 October 1963. At 10:39 pm, between 240 and 300 millions $\mathrm{m}^{3}$ of rock detached from Mount Toc, in Veneto (northern-eastern Italy), and slid into the Vajont Lake. The rockslide pushed the water against Casso and
Erto, two small hamlets on the slope in front of the slope of Mount Toc that failed in the disaster, and then over an artificial dam. A water wave several meters high overtopped the dam and reached the town of Longarone at 10:46 pm, destroying it. The Vajont landslide killed at least 1921 people, of which seven at San Martino, at least 151 at Frasègn, le Spesse, Cristo, Pineda, Ceva, Prada, Marzana, 54 at a construction camp near the dam, 109 in the town of Castellavazzo and at least 1759 between the town of Longarone and the area downstream along the Piave valley (http://www.vajont.net; Catenacci, 1992). News about the Vajont disaster reached the United States; the Herald Tribune titled: "Vajont Dam: Warning Ignored".

- 3-4 November 1966. The city of Florence (Tuscany, central Italy) was inundated by a severe flood of the Arno River. The flood caused severe damage throughout Tuscany, and in particular in the Arno basin, and produced a tremendous impact on the cultural heritage, mostly in Florence. Many masterpieces of the Italian Renaissance, including the church of Santa Croce and its square, the Christ by Cimabue, paintings by Vasari, Paolo Uccello and Botticelli, together with 3000 artpieces and 1500000 historical documents in the Museum of Santa Croce and at the National Library were damaged or destroyed (Becchi, 1999). In Tuscany 48 people were killed and 7 persons were missing in 5 provinces. Evacuated and homeless people were more than 46600. The 1966 inundation of the Arno River was the last in a series of more than fifty flooding events occurred in Florence since 1177, of which the most severe occurred in $1177,1269,1288,1333,1380,1589$, 1740, 1844 and 1864 (Natoli, 1944; Becchi, 1999). The same meteorological event that caused the inundation in Florence dropped high intensity rainfall in the Western Alps, causing extensive inundations and numerous landslides in Trentino-Alto Adige, Veneto, Friuli-Venezia Giulia and to a more limited extent in Emilia-Romagna. Fatalities caused by landslides and floods in north-eastern Italy were 88 in eight provinces, namely: Bolzano (5), Trento (25), Belluno (29), Treviso (2), Venezia (3), Vicenza (5), Udine (15) and Pordenone (4). The evacuated people exceeded 42,000 , of which 25800 in Veneto, 15800 in Friuli-Venezia Giulia, 800 in Emilia-Romagna and 410 in Trentino-Alto Adige. In the Po and Veneto plains, at least $137 \mathrm{~km}^{2}$ of land were inundated. Damage was reported in at least $209 \mathrm{mu}-$ nicipalities. In the Belluno province more than 4300 buildings, 528 bridges, and 1346 roads were destroyed or damaged (Catenacci, 1992). On 4 November the water level in the Venice lagoon reached $194 \mathrm{~cm}$ above datum, and the city was inundated by up to $100 \mathrm{~cm}$ of water for more than $15 \mathrm{~h}$. It is the most severe flooding on record for the 20th century (Comerlati et al., 2003).

- 7-8 October 1970. The city of Genoa (Liguria, northwestern Italy) was inundated by the Polcevera, Leiro 
and Bisagno rivers that went over the banks at several locations. A localized, but very intense rainstorm dropped more than $900 \mathrm{~mm}$ of rain in $24 \mathrm{~h}$, which was about $90 \%$ of the mean annual precipitation. The city of Genoa suffered the most severe losses, but damage was reported in other 20 municipalities in the Genoa and Alessandria provinces. Major roads and 2 railroads were interrupted by flooding and landslides at various locations. The toll amounted to 44 casualties, including 35 deaths, 8 missing persons and 1 injured person. The evacuees were at least 2000 and homeless people were at least 185. The economic loss in Genoa was estimated at 45 billion 1970/Lire (Fig. 1). Damage to the cultural heritage was also severe. The lower floors of tens of historical buildings in the medieval centre of Genoa (which is one of the largest in Europe) were inundated.

- 13 December 1982. At 10:45 pm, a large, deepseated landslide occurred at Ancona (Marche, central Italy). The single slope failure involved the movement of 342 hectares of urban and suburban land, damage to two hospitals and the Faculty of Medicine at Ancona University, damage to or complete destruction of 280 buildings with a total of 865 apartments, displacement of the main railway and coastal road for more than 2.5 $\mathrm{km}, 1$ death (and indirectly at that, as it was a man in a hospital who suffered a hearth attack), and the evacuation of 3661 people (1071 families). At least 500 people were left temporarily unemployed (Crescenti, 1986). The economic loss was estimated at 1000 billion 1982/Lire (Alexander, 1989) (Fig. 1).

- 19 July 1985. At 12:24 am, two artificial mine ponds near Tesero (Trento Province, northern Italy) failed producing the largest single mudflow in Italy in historical time (Tosatti, 2003). More than 230 millions $\mathrm{m}^{3}$ of muddy debris flowed at sustained speed along the Stava stream, reaching in $7 \mathrm{~min}$ the town of Tesero. At this site deaths and missing persons were 268, and the injured people at least 30 . About 70 buildings were destroyed or severely damaged (Catenacci, 1992). The economic loss was estimated at 8.5 billion 1985/Lire (Fig. 1). After the 1953 landslide disaster at Vajont, and the 1 December 1923 failure of the Gleno dam (in Valcamonica), the Tesero mudflow represents the third largest catastrophe in Italy in the 20th century caused by or associated with an artificial embankment or a dam.

- 17-19 July 1987. In Valtellina (Lombardy, northern Italy) heavy rainfall produced flooding along the Adda river and its tributaries, and triggered several hundreds debris flows, a few deep-seated landslides, and a catastrophic rock avalanche 35 millions $\mathrm{m}^{3}$ in volume (on 28 July). The rock avalanche deposit dammed the Adda River and formed an ephemeral lake. Casualties amounted to 49 deaths, 12 missing persons and 31 injured people, of which 27 deaths and 9 injured people were the direct result of the rock avalanche. As many as
20000 people were evacuated downstream of the landslide dam, along the Adda valley. Damage was reported in 162 Municipalities in 5 provinces (Sondrio, Como, Lecco, Bergamo and Brescia). The economic loss was estimated in the range between 1000 and 2000 billion 1987/Lire (Guzzetti et al., 1992) (Fig. 1).

- 2-6 November 1994. Extensive inundation and numerous landslides in Piedmont (north-western Italy) resulted in 172 casualties, including 78 deaths, one missing person and 93 injured people. Evacuees and homeless people were 9500. At least 496 municipalities suffered damage that was particularly severe to the infrastructure. Ten bridges were destroyed and more than 100 were damaged. At several locations, roads were destroyed by shallow and deep-seated landslides for several hundreds meters, leaving towns and villages isolated for weeks. Ten thousands people were left temporarily unemployed. The Tanaro River caused the largest damage, particularly in and in the vicinity of Alba, Asti and Alessandria (Regione Piemonte, 1998). Estimates of the economic loss ranged between 15000 and 25000 billion 1994/Lire (Fig. 1), 1.2\% of 1994 gross domestic product (GDP).

- 5 May 1998. A rainfall event on the steep slopes of Pizzo d'Alvano, east of Naples (Campania, southern Italy) triggered numerous debris flows that involved unconsolidated volcanic soils. Several pulses of mud and debris inundated the towns of Episcopio, Siano, Bracigliano and Quindici, resulting in 157 deaths, 5 missing persons and 70 injured people in at least 13 different sites, and leaving a few hundreds of homeless people. The event caused a tremendous impact nationwide, which included unprecedented coverage by the mass media, and prompted a new legislation on landslide risk assessment procedures (Vallario, 1991).

- 13-16 October 2000. The Po River and its northern (i.e. left) tributaries experienced the first large flood of the 21 st century. In the western Alps, rainfall in excess of $600 \mathrm{~mm}$ in $48 \mathrm{~h}$ produced landslides, debris flows and inundations in Valle d'Aosta, Piedmont and Liguria. In Torino (Piedmont) the Po River was only a few centimetres from the top of the levees, and at Ivrea (Piedmont) the Dora Baltea River inundated part of the town. In Valle d'Aosta damage was particularly severe. At Pollein a debris flow killed 6 people, at Fenis casualties due to a debris flow were 7 , and at Donnas the Dora Baltea River inundated a large part of the valley bottom. The death toll for the entire event amounted to 37 deaths and missing persons (18 in Valle d'Aosta, 5 in Piedmont, 3 in Liguria, 1 in Trentino-Altro Adige and 10 in Ticino Canton, Switzerland). More than 40000 people were evacuated, and at least 3000 were the homeless people. Economic damage was estimated in excess of EUR 5000 million (Regione Piemonte, 2000a, 2000b; Ratto et al., 2003) (Fig. 1). 
Acknowledgements. We acknowledge the work of the people who contributed to the compilation of the AVI database. We are indebted to $\mathrm{C}$. Bianchi for collecting information on recent flood and landslide disasters, to P. Reichenbach and F. Ardizzone for preparing some of the figures, and to M. Guadagno and V. Balducci for helping managing the information system. We are grateful to P. Gori and M. J. Roberts for their useful comments. Research supported by GNDCI CNR grants in the period 1992 to 2002. This paper is GNDCI CNR publication number 2821 .

Edited by: R. Couture

Reviewed by: P. Gori and M. J. Roberts

\section{References}

Agostoni, S., Laffi, R., and Rossetti, R.: Centri abitati instabili della Provincia di Pavia (in Italian), Regione Lombardia and CNR Gruppo Nazionale per la Difesa dalle Catastrofi Idrogeologiche Publication number 1780, Milano, Italy, 1997a.

Agostoni, S., Laffi, R., and Sciesa, E.: Centri abitati instabili della Provincia di Sondrio (in Italian), Regione Lombardia and CNR Gruppo Nazionale per la Difesa dalle Catastrofi Idrogeologiche publication number 1580, Milano, Italy, 1997b.

Agostoni, S., Cantone, G., Laffi, R., Ratti, R., and Sciunnach, D.: Centri abitati instabili della Provincia di Lecco, (in Italian), Regione Lombardia e CNR Gruppo Nazionale per la Difesa dalle Catastrofi Idrogeologiche Publication number 2066, Arti Grafiche Vertemati, Vimercate (MI), 2000.

Alexander, D.: Urban landslides, Progr. Phys. Geogr., 13:2, 157191, 1989.

Almagià, R.: Studi Geografici sopra le frane in Italia, Volume I, Parte generale - L'Appennino Settentrionale e il Preappennino Tosco-Romagnolo (in Italian), Società Geografica Italiana, Rome, 13, 1907.

Almagià, R.: Studi Geografici sopra le frane in Italia, Volume II, L'Appennino centrale e meridionale - Conclusioni generali (in Italian), Società Geografica Italiana, Roma, 14, 1910.

Annovi, A. and Simoni, G.: Atlante dei centri abitati instabili dell'Emilia Romagna (in Italian), Regione Emilia-Romagna e CNR Gruppo Nazionale per la Difesa dalle Catastrofi Idrogeologiche Publication number 1430, Stabilimento Salomone, Roma, 6 volumes, 1993.

Baratta, M.: I terremoti d'Italia, Saggio di storia, geografia e bibliografia sismica italiana (in Italian), Torino, 1901.

Becchi, I.: Ricordare l'alluvione, Omaggio alla Città di Firenze Alluvionata, CD-ROM, in: La difesa dalle alluvioni (in Italian), edited by Falciai, M. and Preti, F., CNR Gruppo Nazionale per la Difesa dalle Catastrofi Idrogeologiche Publication n. 1963, Tecnoprint, Bologna, 1999.

Bellardone, G.: Eventi alluvionali in Piemonte nel XX secolo, in: Gli eventi alluvionali del settembre-ottobre 1993 in Piemonte, Assessorato Ambiente, Cave e Torbiere, Energia, Pianificazione e Gestione delle Risorse Idriche (in Italian), Lavori Pubblici e Tutela del Suolo, Settore per la Prevenzione del Rischio Geologico, Meteorologico e Sismico, Torino, 12-14, 1996.

Boschi, E., Guidoboni, E., Ferrari, G., Valensise, G., and Gasperini, P.: Catalogo dei forti terremoti in Italia dal 461 a.C. al 1990 (in Italian), ING-SGA, Bologna, 1997.

Bozzo, G. P., Friz, C., Pasuto, A., Scaramuzza, L., and Silvano, S.: Centri abitati instabili della Regione del Veneto,
Prima indagine conoscitiva (in Italian), Regione Veneto and CNR Gruppo Nazionale per la Difesa dalle Catastrofi Idrogeologiche Publication number 90, Padova, Italy, 1988.

Cannarozzo, M., D‘Asaro, F., and Ferro, V.: Valutazione delle piene in Sicilia (in Italian), CNR Gruppo Nazionale per la Difesa dalle Catastrofi Idrogeologiche Publication number 1431, 1993.

Cao, C., Piga, E., Salis, M., and Sechi, G. M.: Valutazione delle piene in Sardegna, Rapporto Regionale Sardegna (in Italian), CNR Gruppo Nazionale per la Difesa dalle Catastrofi Idrogeologiche Publication number 1418, 1991.

Cardinali, M., Carrara, A., Donzellini, G., Giovetti, S., Guzzetti, F., Menegatti, P., Reichenbach, P., and Tonelli, G.: MAPPAVI, Software per la visualizzazione del Catalogo delle informazioni storiche sulle località colpite da frane ed inondazioni censite dal progetto AVI (in Italian), CNR Gruppo Nazionale per la Difesa dalle Catastrofi Idrogeologiche Publication number 1800, Version 1.2, 1998a.

Cardinali, M., Cipolla, F., Guzzetti, F., Lolli, O., Pagliacci, S., Reichenbach, P., Sebastiani, C., and Tonelli, G.: Catalogo delle informazioni sulle località italiane colpite da frane e da inondazioni (in Italian), 2 volumes, CNR Gruppo Nazionale per la Difesa dalle Catastrofi Idrogeologiche Publication number 1799, 1998b.

Canuti, P., Focardi, P., Nardi, R., and Puccinelli, A.: Atlante dei centri abitati instabili della Toscana (in Italian), CNR Gruppo Nazionale per la Difesa dalle Catastrofi Idrogeologiche Publication number 2143, Stabilimento Poligrafico Fiorentino, Calenzano (FI), 2000.

Catenacci, V.: Il dissesto geologico e geoambientale in Italia dal dopoguerra al 1990, Memorie Descrittive della Carta Geologica d'Italia (in Italian), Servizio Geologico Nazionale, 1992.

Coe, J. A., Michael, J. A., Crovelli, R. A., and Savage, W. Z.: Preliminary map showing landslide densities, mean recurrence intervals, and exceedance probabilities as determined from historic records, Seattle, Washington, U.S. Geological Survey Open File Report 00-303, internet version, http://greenwood.cr.usgs. gov/pub/open-file-reports/ofr-00-0303/, 2000.

Collalti, M., Monteleone, S., and Pipitone, G.: Atlante dei Centri abitati instabili della Regione Sicilia, Vol. I, Provincia di Trapani (in Italian), CNR Gruppo Nazionale per la Difesa dalle Catastrofi Idrogeologiche, Publication number 2509, 2002.

Comerlati, A., Ferronato, M., Gambolati, G., Putti, M., and Teatini, P.: Can $\mathrm{CO}_{2}$ help save Venice from the sea? EOS, Transactions, AGU, 84:49, 9, December 2003, 546, 552-3, 2003.

Copertino, V. and Fiorentino, M.: Valutazione delle piene in Puglia (in Italian), CNR Gruppo Nazionale per la Difesa dalle Catastrofi Idrogeologiche Publication number 1437, 1994.

Crescenti, U.: La grande frana di Ancona del 13 dicembre 1982 (in Italian), Studi Geologici Camerti, Special Issue, Camerino, 1, 1986.

Crovelli, R. A.: Probability models for estimation of number and costs of landslides, U.S. Geological Survey Open File Report 00-249, internet version, http://greenwood.cr.usgs.gov/pub/ open-file-reports/ofr-00-0249/, 2000.

D’Andrea, E., Petrucci, O.: Gli eventi alluvionali Calabresi di dicembre 2002 - gennaio 2003 (in Italian), CNR Gruppo Nazionale per la Difesa dalle Catastrofi Idrogeologiche, Publication 2815, Editoriale Bios, Cosenza, 2003.

Eisbacher, G. H. and Clague, J. J.: Destructive Mass Movements in High Mountains: Hazard and Management, Geological Survey of Canada, Paper 84-16, 1984.

Fastelli, C.: Sintesi 1985-2001, Attività e Legislazione, Volume I (in Italian), CNR Gruppo Nazionale per la Difesa dalle Catastrofi 
Idrogeologiche, Perugia, 2003a.

Fastelli, C.: Sintesi 1985-2001, Catalogo delle Pubblicazioni, Volume II (in Italian), CNR Gruppo Nazionale per la Difesa dalle Catastrofi Idrogeologiche, Perugia, 2003b.

Federici, P. R., Baldacci, F., Petersi, A., and Seriani, A.: Atlante dei centri abitati instabili della Liguria, I - Provincia della Spezia (in Italian), Regione Liguria e CNR Gruppo Nazionale per la Difesa dalle Catastrofi Idrogeologiche, Publication number 2270, Tipolitografia Nuova ATA, Genova, 2001.

Felciai, M. and Preti, F.: La difesa dalle alluvioni, Proceedings Convegno Scientifico Trentennale dell'Alluvione di Firenze, Florence, 4-5 November 1996 (in Italian), CNR Gruppo Nazionale per la Difesa dalle Catastrofi Idrogeologiche, Publication number 1963, Tecnoprint, Bologna, 1996.

Felicioni, G., Martini, E., and Ribaldi, C.: Studio dei Centri Abitati Instabili in Umbria, Atlante Regionale (in Italian), Regione dell'Umbria e CNR Gruppo Nazionale per la Difesa dalle Catastrofi Idrogeologiche, Publication number 979, Rubettino, Catanzaro, 1995.

Gabriele, S.: Crotone e l'evento alluvionale del 14 Ottobre 1996, CNR Gruppo Nazionale per la Difesa dalle Catastrofi Idrogeologiche (in Italian), Publication number 1963, 1997.

Govi, M. and Turitto, O.: Ricerche bibliografiche per un catalogo sulle inondazioni, piene torrentizie e frane in Valtellina e Valchiavenna, Associazione Mineraria Subalpina (in Italian), Quaderni di Studi e Documentazione, Quaderno 16, 1994.

Guida, M., Iaccarino, G., Metcalf, G., and Vallario, A.: Bibliografia delle Frane dal 1900 al 1978 (in Italian), Consiglio Nazionale delle Ricerche, IT ISSN 0085-2309, vol. XL, Roma, 1979.

Gutenberg, B. and Richter, C. F.: Seismicity of the Earth and Associated Phenomena, Princeton University Press, Princeton, 1954.

Guzzetti, F.: Landslide fatalities and evaluation of landslide risk in Italy, Engineering Geology, 58, 89-107, 2000

Guzzetti, F. and Cardinali, M.: Debris-flow phenomena in the Central Apennines of Italy, TerraNova, 3, 619-627, 1992.

Guzzetti, F., Cardinali, M., and Reichenbach, P.: The AVI Project: A bibliographical and archive inventory of landslides and floods in Italy, Environmental Management, 18, 623-633, 1994.

Guzzetti, F., Cardinali, M., and Reichenbach, P.: Map of sites historically affected by landslides and floods, The AVI Project, CNR Gruppo Nazionale per la Difesa dalle Catastrofi Idrogeologiche Publication number 1356, scale 1:1 200 000, 1996.

Guzzetti, F., Crosta, G., Marchetti, M., and Reichenbach, P.: Debris flows triggered by the 17-19 July 1987 storm in the Valtellina area (Northern Italy), Proceedings Interpraevent 1992, Berne, 2, 193-204, 1992.

Guzzetti, F., Salvati, P., and Stark, C. P.: Evaluation of flood and landslide risk to people in Italy, Environmental Management, in press, 2004.

Guzzetti, F., Reichenbach, P., Cardinali, M., Ardizzone, F., and Galli, M.: Impact of landslides in the Umbria Region, Central Italy, Natural Hazards and Earth System Sciences, 5, 5/6, 1-17, 2003.

Luino, F., Ramasco, M., and Susella, G.: Atlante dei centri abitati instabili piemontesi (in Italian), Regione Piemonte e CNR Gruppo Nazionale per la Difesa dalle Catastrofi Idrogeologiche Publication number 964, L'Artistica Savigliano pub., Savigliano, 1993.

Mercalli, G.: Vulcani e fenomeni vulcanici in Italia (in Italian), Milano, 1883.

Migale, L. S. and Milone, A.: Ricerca Storica sulle colate di fango in terreni piroclastici della Campagna (in Italian), CNR Gruppo
Nazionale per la Difesa dalle Catastrofi Idrogeologiche, UO 2.38, Unpublished Final Report, 1998.

Monticelli, P.: Ricostruzione storica degli eventi alluvionali nelle Valli di Lanzo tra il 1400 ed il 1900 (in Italian), Regione Piemonte, Direzione Servizi Tecnici di Prevenzione, Quaderno $12,1998$.

Mortara, G., Sorzana, P. F., and Villi, V.: L'evento alluvionale del 6 agosto 1985 nella vallata del Fiume Isarco tra Fortezza ed il Passo del Brennero (in Italian), Memorie di Scienze Geologiche, Padova, 38, 427-457, 1986.

Natoli, E.: Le piene dell'Arno e I provvedimenti di difesa, Accademia d'Italia (in Italian), Commissione italiana di studio per il soccorso alle popolazioni, Florence, 12, 3-362, 1944.

Postpischl, D.: Catalogo dei terremoti italiani dall'anno 1000 al 1980 (in Italian), CNR Progetto Finalizzato Geodinamica, Quaderni de "La Ricerca Scientifica", 114:2B, Roma, 1985.

Potenza, R., Carrara, A., Guzzetti, F., and Signore, O.: Integrated access to earth science data, Proceedings Congress International Association Mathematical Geology, Ischia, 5 October 1998, 676-682, 1998.

Ratto, S., Bonetto, R., and Comoglio, C.: The October 2000 flooding in Valle d'Aosta (Italy), Event description and land planning measures for risk mitigation, Int. Journal. River Basin Management, 1, 2, 105-116, 2003.

Regione Piemonte: Gli eventi alluvionali del settembre-ottobre 1993 in Piemonte, Assessorato Ambiente, Cave e Torbiere, Energia, Pianificazione e Gestione delle Risorse Idriche, Lavori Pubblici e Tutela del Suolo, Settore per la Prevenzione del Rischio Geologico (in Italian), Meteorologico e Sismico, Torino, 1996.

Regione Piemonte: Eventi Alluvionali in Piemonte: 2-6 novembre 1994, 8 luglio 1996, 7-10 ottobre 1996 (in Italian), Direzione Servizi Tecnici di Prevenzione, Torino, 1998.

Regione Piemonte: Rapporto sull'evento alluvionale del 13-16 ottobre 2000, Parte I, L'attività di previsione e monitoraggio meteoidrometrica (in Italian), http://www.regione.piemonte.it/ alluvione/dwd/rapp1.pdf, (accessed July 2001), 2000a.

Regione Piemonte: Rapporto sull'evento alluvionale del 13-16 ottobre 2000, Parte II, Effetti sulle aree antropizzate: Quadro preliminare (in Italian), http://www.regione.piemonte.it/alluvione/ dwd/rapp2.pdf (accessed July 2001), 2000b.

Reichenbach, P., Cardinali, M., De Vita, L., and Guzzetti, F.: Regional hydrological thresholds for landslides and floods in the Tiber River basin (Central Italy), Environmental Geology, 35, 2 3, 146-159, 1998a.

Reichenbach, P., Guzzetti, F., and Cardinali, M.: Map of sites historically affected by landslides and floods, Second edition, CNR Gruppo Nazionale per la Difesa dalle Catastrofi Idrogeologiche Publication number 1786, scale 1:1 200 000, 1998b.

Rossi, F. and Villani, P.: Valutazione delle piene in Campania, Rapporto Regionale Campania (in Italian), CNR Gruppo Nazionale per la Difesa dalle Catastrofi Idrogeologiche Publication number 1470, 1995.

Rosso, R. and Serva, L.: 19 Giugno 1996, Alluvione in Versilia e Garfagnana, Un caso di studio, Agenzia Nazionale per l'Ambiente e Agenzia Regionale per l'Ambiente ed il Territorio (in Italian), Litografia IP, Firenze, 1998.

Tosatti, G.: A Review of scientific contributions on the Stava Valley disaster (eastern Italian Alps), 19th July 1985, CNR Gruppo Nazionale per la Difesa dalle Catastrofi Idrogeologiche Publication number 2807, Pitagora, Bologna, 2003

Troisi, C.: Esame di alcuni dati storici relativi ad eventi alluvionali e fenomeni di instabilità naturale nelle valli dei torrenti Orco e 
Soana, Alto Canavese, Provincia di Torino, Regione Piemonte, Settore per la Prevenzione del Rischio Geologico (in Italian), Meteorologico e Sismico, Torino, 1997.

Tropenano, D.: Eventi alluvionali e frane nel bacino della Bormida, Studio retrospettivo (in Italian), Associazione Mineraria Subalpina, Quaderni di Studio e di Documentazione, 10, Supplemento al Bollettino n. 4, Torino, 1989.

Tropeano, D. and Turconi, L.: Sintesi degli eventi di piena e frana avvenuti nell' anno 2000 in Italia nord occidentale (in Italian), GEAM Geoingegneria Ambientale e Mineraria, Territorio e Difesa del Suolo, Torino, 217-224, 2000.

Tropeano, D. and Turconi, L.: L'evento del 13 giugno 2000 nelle Alpi Occidentali: effetti sui versanti e nella rete idrografica (in Italian), CNR Gruppo Nazionale per la Difesa dalle Catastrofi Idrogeologiche Publication number 2507, 2002.

Tropeano, D., Chiarle, M., Deganutti, A., Mortara, G., Moscariello, A., and Mercalli, L.: Gli eventi alluvionali del 22 e 27 settembre 1992 in Liguria, Studio idrologico e geomorfologico, (in Italian), GEAM, Associazione Georisorse e Ambiente, Quaderni di Studi e Documentazione, 13, 30:4, 1993.

Tropeano, D., Arattano, M., Deganutti, A. M., Luino, F., Ciarmatori, L., and Dutto, F.: L'evento alluvionale del 23-25 settembre 1993 in Liguria, Piemonte e Valle d'Aosta, Aspetti Geologici e Geomorfologici, (in Italian), GEAM, Associazione Georisorse e Ambiente, Quaderni di Studi e Documentazione, 18, 32:2-3, 1995.
Tropeano, D., Govi, M., Mortara, G., Turitto, O., Sorzana, P., Negrini, G., and Arattano, M.: Eventi alluvionali e frane nell'Italia Settentrionale (in Italian), CNR Gruppo Nazionale per la Difesa dalle Catastrofi Idrogeologiche Publication number 1927, 1999.

Tropeano, D., Luino, F., and Turconi, L.: Evento alluvionale del 14-15 ottobre nell'Italia nord orientale, Fenomei ed effetti (in Italian), GEAM Geoingegneria Ambientale e Mineraria, Torino, 203-216, 2000.

Vallario, A.: Il dissesto idrogeologico in Campania (in Italian), CUEN s.r.1., Napoli, 2001.

Versace, P., Ferrari, E., Fiorentino, M., Gabriele, S., and Rossi, F.: La valutazione delle piene in Calabria, (in Italian), CNR Gruppo Nazionale per la Difesa dalle Catastrofi Idrogeologiche Publication number 987, 1987.

Villi, V. and Bacchi, B.: Valutazione delle piene nel Triveneto (in Italian), CNR Gruppo Nazionale per la Difesa dalle Catastrofi Idrogeologiche Publication number 2511, 2001. 